\title{
Re-directing Climate Change and Terrorism by Allying Classical with Quantum Neural Computing
}

\author{
Antonio Cassella ${ }^{1}$ \\ ${ }^{1}$ President of Research Autism LLC (FL) and Director of Imerisya (Instituto merideño de investigación de la inteligencia \\ social y del autismo, Mérida, Venezuela). \\ Correspondence: Antonio Cassella, 1270 N. Wickham Rd. 16-613, Melbourne, FL, 32935, USA.
}

Received: March 24, 2017

Accepted: May 23, $2017 \quad$ Available online: May 24,2017

doi:10.11114/ijsss.v5i6.2439

URL: https://doi.org/10.11114/ijsss.v5i6.2439

\begin{abstract}
Before the turn of the $21^{\text {st }}$ century, terrorism and climate change may cause the breakdown of civilization. The cause of this advancing upheaval is the disparity between scientific ascent and social descent. This paper explores the social values hidden in sacred texts and artistic masterpieces through a view of an impaired capacity for renewing familiar reality in Autism Spectrum Disorder (ASD), as well as an impaired ability to preserve shared beliefs in Schizophrenia Spectrum Disorders (SSD). The author posits that we will overcome climate change and terrorism if we join our capacity for renovating and preserving shared knowledge to a humanistic use of science and technology.
\end{abstract}

Keywords: autism, classical computing, quantum computing, social intelligence, global warming, terrorism

\section{Introduction}

In this paper I hypothesize that adding the knowledge of the roots of social intelligence to our scientific and technological skills will allow us to re-direct global warming and fundamentalism into a humanistic civilization. From the late 1990s to the late 2000s I developed a controversial psychological heuristic, which I call "lo gos," by researching the difficulties people with Autism Spectrum Disorders (ASD) have with pretend play, false-belief tasks, art metaphor, the deixis of pronouns, and unforeseen changes of context (Cassella, 1997, 2000, 2002a, 2002b, 2008).

The backbone of logos is described in the following three hypotheses.

1. The illusion of conserving visible routines obeys the classical mode of neural computing preserved in high-functioning autism and hindered in schizophrenia, henceforth referred to as the first attention.

2. Invisible renovation follows the quantum mode of information processing weakened in autism and schizophrenia, henceforth referred to as the second attention.

3. Civilizations and natural systems flourish through the reciprocal empowerment of the first and the second attention, henceforth referred to as the third attention. ${ }^{1}$

For the last 10 years, I have explored the psychological (Cassella, 2011), the neurobiological (Cassella, 2013); the social (Cassella, 2016a); the artistic (Cassella, 2016b); and the universal effects (Cassella, 2016c) of the attentions above.

\section{Method}

In the following Background exposition, I highlight ancient examples of our inclination for conservation and of the dreams of renovation that abandon autistic individuals before the age of three years.

In the Discussion I use the issues outlined in the Background to combine the classical principles of conservation with the quantum principles of renovation in fostering the progress of humans and nonhuman species.

I close the Discussion by suggesting that finding what remains of Leonardo's vanished Battaglia di Anghiari in the Hall of the Five Hundred at the Palazzo Vecchio of Florence may help any self dream with and help any other.

In my concluding remarks I re-interpret the Biblical exposition of an empowered Pharaoh who helped many others by

\footnotetext{
${ }^{1}$ The word "attention" here includes the concepts of both "attention" and "intention."
} 
marrying his nocturnal dreaming with the diurnal dreaming of a powerless stranger — the first Joseph.

\title{
3. Background
}

\subsection{A View of the Main Causes of Global Havoc in the $21^{\text {st }}$ Century}

The letter that Senator Edward Kennedy wrote to me in 2007 reinforced my decision to explore in greater depth the perils and the prospects generated by the rise of fundamentalist-driven terrorism and climate change (Cassella, 2016a).

BOWARD ME KENNEQY

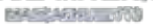

\section{United States Senate}

\author{
WASHIWGDON, DE 20570-210:
}

May 14,2007

Antonio Cassella Ed.D.

1069 June Drive

Melbourne, FL 32935

Dear Mr. Cassella:

Thank you for your recent correspondence regarding global warming and fundamentalism. I sbare your concerns

During my tenure in the Senate, I have worked hard to enact legislation to combat pollution. preserve our environment and natural resources, and provide protection to endangered species. I feel strongly that we must work harder to decrease the amount of pollutants discharged into out oceans. barbors, rivers, and lakes, and to reduce the emissions that pollute the air we breathe:

The problem of global elimate change is real and growing. After years of insistiog that it was unclear whether global climate change was manmade or natural, even President Bush has recently begun to discuss the "gerious challenge of global climate change." However, the administration, and Congress, must back up its words with actions. The industries responsible for much of the world's emissions are strongly opposing efforts to deal offectively with the problem. Thus, it is lett to Congress to introduee legislation designed to control global warming, including laws requiring higher fuel standards and investment into sources of renewable energy.

With regurd to the challenge of global fundamentalism, 1 believe that this issue must be addressed in conjunction with our friends and allies around the world. The Bush Doctrine of unilateral action has been destroyed by the ongoing tragedy in Iraq. Only by working with the other nations of the world can truly global issues such as global warming and fundementalist-driven terrorism be addressed.

Thank you again for sending me your Power Point presentation on global varming. Educating the public about the dangers of Blobal climate change is an enormous task that requires contributions from all citizens. Much remains to be done to ensure the preservation of our. environment. These batlles are never easy, but I look forward to progress toward achieving these important goals.

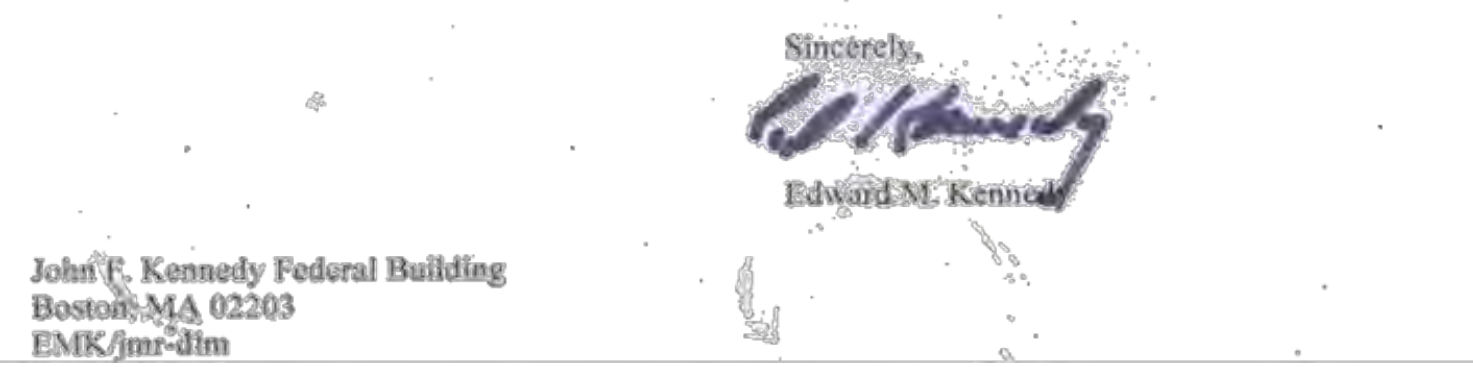

Figure 1. Letter of Senator Edward Kennedy to Antonio Cassella on global warming and Fundamentalism 
Edward Kennedy's letter implies that we can challenge the advance of global warming and fundamentalist-driven terrorism with a renewed hope. I hope that my unconventional view of the natural relationship between the autistic principles of conservation and the artistic principles of renovation will impact the minds of the malicious individuals that try to drown the second attention in the normal young. I also hope to reach the second attention of the deniers of global warming before they make a deal with the devil.

\subsection{A View of the Phenomenon of Global Warming}

In its Fifth Assessment Report (AR5, 2014), the Intergovernmental Panel on Climate Change (IPCC) established several scenarios. I will provide a brief summary of the last IPCC's report by recapping the edges of the mantle that covers their scenarios.

a) In the lowest emission pathway (RCP 2.6), the present concentration of carbon dioxide $\left(\mathrm{CO}_{2}\right)$ in the atmosphere - about $400 \mathrm{ppm}$ (parts per million), or $0.04 \%$ - will grow to nearly $450 \mathrm{ppm}$ by mid century, before its abatement to about $430 \mathrm{ppm}$ by the end of the $21^{\text {st }}$ century.

b) In the highest emission pathway (RCP 8.5), the concentration of $\mathrm{CO}_{2}$ will reach about $1350 \mathrm{ppm}$ by the end of this century.

The corresponding average temperature upturns of the atmosphere by the end of the $21^{\mathrm{s}}$ century -at sea level, and in degrees Celsius $\left({ }^{\circ} \mathrm{C}\right)$ - will be one degree and six degrees. The minimum and maximum increases in sea level would be $0.4 \mathrm{~m}$ (meter) and $0.9 \mathrm{~m}$.

Although it is conservative, the mantle provided by the IPCC implies that the rise of the average temperature of the atmosphere at sea level during the $21^{\mathrm{s}}$ century responds to our wild exploitation of the Commons of the Earth - among them, the oceans and the air we breathe. Valuing the number of particles that the Italian Amedeo Avogadro assigned about 200 years ago to one mole of any substance, $6.022140857 \times 10^{23}$, every time we breathe we inhale one particle of the very air that ran through the lungs of Abraham, Jesus, and Muhammad. There are no social values in forcing our grandchildren to breathe an air warmer than the one inhaled by the advocates of social values in the sacred texts of any culture.

Figure 2 shows an overall picture of the anthropic mechanism of the atmospheric accumulation of carbon dioxide $\left(\mathrm{CO}_{2}\right)$.

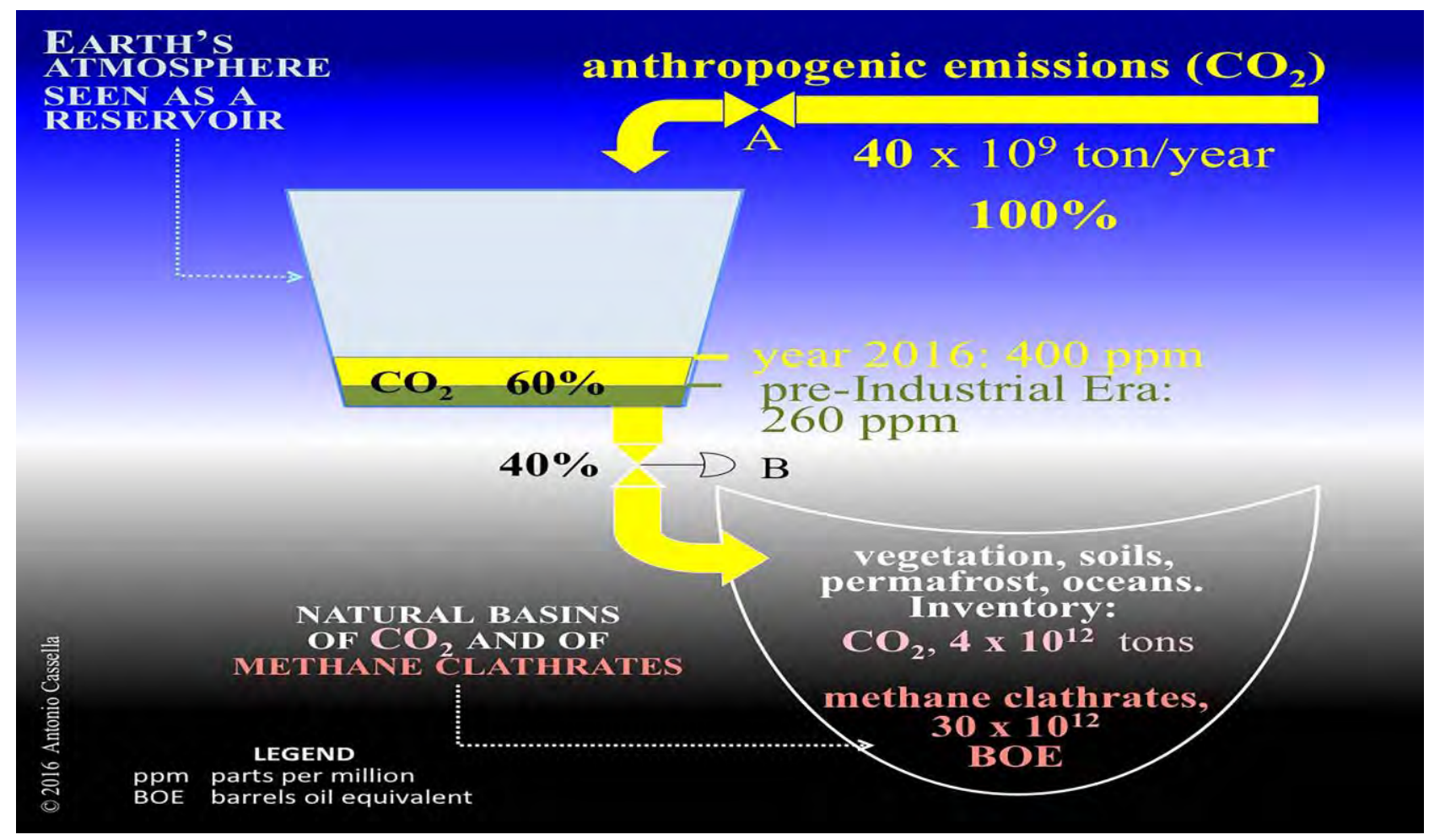

Figure 2. Sketch of the Carbon Cycle

By the end of 2016, the content of $\mathrm{CO}_{2}$ in Earth's atmosphere was $400 \mathrm{ppm}$ (parts per million) - $140 \mathrm{ppm}$ above the level of the pre-Industrial era $(260 \mathrm{ppm})$. Notice the unnatural result by which $60 \%$ of the anthropic emissions of $\mathrm{CO}_{2}$ do not return to the earth.

The increase in the atmospheric content of $\mathrm{CO}_{2}$ since the onset of the Industrial Revolution in 1760 agrees with the 
tenfold rise of both global population and the average per-capita consumption of energy in the last 26 decades.

Global warming also responds to the natural increase of the heat conveyed by the Sun into the Earth. Indeed, Milutin Milankovitch theorized in the 1920s that periodical changes on the climate of our planet respond to variations in the eccentricity, obliquity, and precession of Earth's movements in the solar system (Milankovitch, 1998). Although Milankovitch analyzed the past 600000 years, Hays, Imbrie, and Shackleton (1976) validated his theory in the last 450 000 years. For example, 125000 years ago an average temperature of the lower atmosphere $3^{\circ} \mathrm{C}$ higher than present day sustained a sea level seven meters higher than today's levels.

Solar forcing reached its minimum about 22000 years ago, when the average temperature of the atmosphere at sea level was $9^{\circ} \mathrm{C}$ lower than present-day temperatures; and sea level, 130 meters lower. About 18000 years ago the temperature of the atmosphere increased to $2^{\circ} \mathrm{C}$ below its present value. Freed by retreating ice and by advancing game, 18000 years ago, a few artists painted roaming bisons on the polychrome ceiling of the Spanish cave of Altamira. It would seem that nature - and not the artistic injudiciousness of our Paleolithic ancestors - forced the rise of the average temperature of the lower atmosphere and the rise of sea level until the dawn of the Industrial Revolution.

At this point in time, should we add to or subtract from natural forces the chaotic force of our schizophrenic injudiciousness?

\subsection{A View of Fundamentalist-driven Chaos}

The hatred and rigid beliefs espoused by the terrorists that destroyed the Twin Towers in 2001 and the hopelessness of the workers that jumped from the windows of the floors they were trapped in demonstrate that order and chaos follow each other. Once we enter a chaotic path, most of us will not be able to grow life-saving wings in a few seconds. And yet, all sacred texts and artistic masterpieces hide the miracle by which quantum neural computing in our minds can suspend the pull of central order, imposed by classical neural computing through obedience to authority. The first readers in human history recognized the sterility of a union exacted by a tyrant.

\subsection{The Failure of the Human Inclination to Obey Unilateral Power in the Epic of Gilgamesh}

The ancient Epic of Gilgamesh stands as the first fiction in human literature. In the recount of Andrew (1999), Gilgamesh, a legendary King of Uruk in the third millennium BCE (before the Common Era), exemplifies the insufficiency of tyrants to save the families that trust the unilateral ways of their leadership. In most versions of the story, Gilgamesh excels in "knowing" first local beauties and in spending others' time to protect his realm with imposing walls. Having news of the existence of Enkidu, a gifted man-beast, Gilgamesh sends a courtesan to bend into his purposes the creative force that animates the forest-based life of the primeval Enkidu.

After one week of Enkidu's exposure to loveless love, his nonhuman friends abandon him. The hairy savage, then, approaches the hairless Gilgamesh with a will to steal the "droit du seigneur" from the King of Uruk. Gilgamesh, however, convinces Enkidu to join him in his fleshly exploits and in providing new doors to the temple of Enlil - the supreme god of any overassertive ideology. In downing the tallest cedar tree around, the two friends kill Humbaba, the monstrous guardian of forests. Their senseless act enrages the Mother of the Earth, Inanna, who sends another monster, Gugalanna, to stop the construction of walls, roads, and the urban expansion favored by Gilgamesh. Enkidu kills Gugalanna, but is wounded in the fight.

The gracious Inanna asks the King of Uruk to share her dreams, but he rejects her ambiguous offer, while Enkidu spurns the goddess forever by throwing rotten pieces of Gugalanna into her midst. The concerned Inanna asks the other immortal gods for the death of the insane Enkidu. After the funeral of his best friend, the seemingly repented Gilgamesh decides to search for immortality by consulting Utnapishtim, the distant sage who survived the first flood. The immortal Utnapishtim acquaints Gilgamesh with the location of the plant of eternal life. The king ties heavy stones to his feet, reaches the bottom of a nearby sea, retrieves the precious entity, and initiates his return to Uruk. While he takes a bath along the lengthy way, however, a devilish serpent steals the valuable plant away.

Gilgamesh lost the plant of the third attention because he obeyed the classical power of his inadequate routines, under the spell of his first attention, or the cognitive staff that the prophet Zechariah called later "Hovalim" ("righteous brotherhood"). Gilgamesh's failure points at the loss of quantum power in his second attention, symbolized by the Enkidu he knew first and by the staff that Zechariah would call later "No'am" (" sensible grace"). The plant of salvation, then, mirrors the union of autistic righteousness and artistic grace, as in the wording "righteous Grace"-or "Jong un" in Korean. 


\subsection{The Staffs "No' am" and "Hovalim" and the Crystals "Urim" and "Thummim"}

In the sixth century BCE, the prophet Zechariah wrote ${ }^{2}$ about the loss of the graceful union of sanity with madness (or the second attention impaired in the autistic spectrum) followed by the loss of shared righteousness (or the first attention spared in autism and impaired in schizophrenia),

'I took for myself two staffs; one I called No'am, and the other Hovalim (11:07)...

And I took my staff No'am and cut it in two to revoke the alliance that I had celebrated with all the tribes (11:10). Later, I cut in two my other staff, Hovalim, so as to break the brotherhood between Judah and Israel." $(11: 14)$.

No one has yet to offer a convincing explanation of the meaning of the staffs "No'am" and "Hovalim." Still, I associate them with the precious stones "Urim" and "Thummim" that Judah and Israel had treasured in the vanished Ark of the Covenant.

However, the fact that in the $19^{\text {th }}$ century the angel Moroni loaned back the crystals Urim and Thummim to Joseph Smith to help him translate the ancient Book of Mormon suggests that the alliance of talent for renovating reality (Urim, No'am, or the or the second attention that abandons autistics before the age of three years) with respect for conserving reality (Thummim, Hovalim, or the first attention that serves the memory of autistic savants) drives the potential growth of the third attention across wheels within wheels in nature and the mind. For example, a verse of the Mormon book Doctrine and Alliances asserts, "The place where God resides is a great Urim and Thummim" (D\&A 130:6/11).

Figure 3 proposes that in all sacred texts, the first attention (1) marks the entrance into the labyrinths (2) of the second attention, which will lead us to "our" third attention (3), if we do not get caught by madness (-1). As implied by Arjuna Ghandivadavan in the Baghavad Gita (Baktivedanta, 1972-1983), Laozi in the Tao Te Ching (Lao Tze, $6^{\text {th }}$ century-1891), and Xbalanqué and Hunahpú in the Popol Vuh (Anonymous, 2003), we join artistic talent to autistic respect (the crystals Urim and Thummin, or the staffs No'am and Hovalim) when we dream with both sides of a confrontation. We cannot do that if we use our Gandiva bow (the second attention) to destroy our opponents.

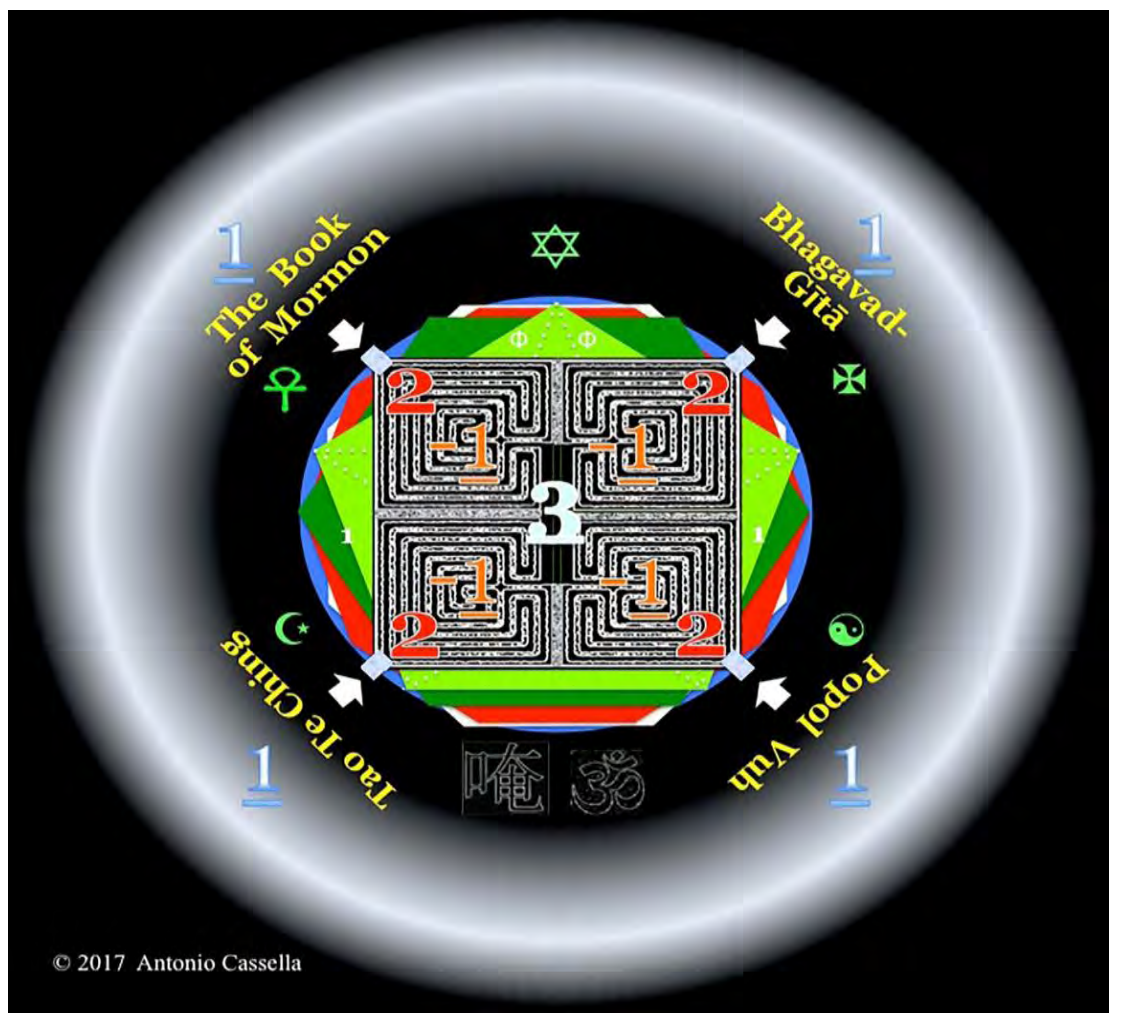

Figure 3. A view of the labyrinths hidden in sacred texts

Few adults lean on their first attention (1) to enter the labyrinths of the second attention (2) in the texts they cherish; fewer ones escape madness (-1) in exiting a labyrinth to embrace "their" third attention (3).

\footnotetext{
${ }^{2}$ My translation from Katznelson(1991).
} 
The third attention (3) reflects the alliance of the first attention ( +1 in autism, opposed to -1 in schizophrenia) with the second attention (2), the staff Hovalim with the staff No'am, or the crystal Thummim with the crystal Urim.

Most adults can read and even memorize a sacred text and a literary masterpiece through their classical computing, but cannot comprehend their hidden riddles through their caged quantum computing. And yet their second attention was free at age four months. King Herod killed any child he could seize because he knew better than anyone else that the second attention animates the smile of children before they are immersed full time in sequential repetition after the age of seven years. The envy of diabolical leaders will always try to stifle in others the union of the first and the second attention, the staffs Hovalim and No'am, or the crystals Thummim and Urim. Thorough brainwashing will kill the unruly spirit of any young pushed by Moloch toward the unilateral goals of deceitful characters.

Few teachers encourage their students to leave behind their shared beliefs in entering their own labyrinths, confront their own problems in the sight of their inner monsters, and come back with a renewed sense of purpose to the world. Psychologists that follow Ivan Pavlov's classical conditioning, John Watson's behaviorism, or the operant conditioning proposed by B. F. Skinner will always deny the spirit behind innate intelligence. That was not the case, however, of Jean Piaget.

\subsection{Increased Human Capacity for Classical and Quantum Meta-representation}

The Swiss psychologist Jean Piaget (1983) researched the development of intelligence in childhood. Piaget found that seven-year-old normal preschoolers surpass any nonhuman animal by meta-representing, or by linking known concepts. He attributed the early growth of human creativity to a peculiar "montage hèrèditaire."

In 1997-2000, I uncovered the material and the spiritual roots of Piaget's "montage hèrèditaire" (Cassella, 1997, 2000) by observing that

a) high-functioning autistics pass tests rooted in classical neural computing (for example, Proper Self [Povinelli, Landau, \& Perilloux, 1996] and Zaitchik's Photo Test [Zaitchik, 1990]); and that

b) they fail tests embedded in quantum neural computing (for example, shifts of attention [Courchesne et al., 1994; Johnson, 1994] and false-belief tasks [Baron-Cohen, Leslie, \& Frith, 1985; Baron-Cohen, 1995]).

In 2002, I deepened the explanation (Caramazza, 1994) of a teacher of mine in Harvard University, who attributed to mental hyperspace our capacity to play with repetitive reality. In the wake of Don Juan, the Mexican teacher of the American anthropologist Carlos Castaneda (Castaneda, 1969, 1991), I ingrained hyperspace in a secondary capacity for divided attention. My scientific and my literary research (Cassella, 2002a, 2002b) also compelled me to posit that autistics and schizophrenics trapped in the spacetime of their first attention cannot fathom the hyperspace created by the second attention.

\subsection{The Rise of the Ghostly Principles of Quantum Neural Computing}

An article by Landry and Bryson (2004) confirmed my initial supposition that spacetime and hyperspace, or the first and the second attention, respond to seemingly opposite principles (Cassella 2008, 2011).

For example, in the experiment undertaken by Landry and Bryson, autistics changed their first attention from one point to another when a light at their left went off and a light at their right went on. However, if the light at their left stayed on while the light at their right went on, most autistics remained focused on the location of the first light. Unlike autistics, most nonautistic subjects looked at each light alternatively, which is equivalent to saying that their second attention tackled an infinite speed by looking at the here and there nonlocated between the two lights.

The finite speed of our autistic facet rejects the infinite speed of our magical facet. Thus most of us ascribe to an unreal magic Harry Potter's ghostly ability to cross the brick wall that hides platform 9 and $3 / 4$ from the eyes of "muggles" in London's King's Cross railway station. In the view of "muggles," illusory magic compels Captain James T. Kirk to deploy absurd ubiquity and coincidence when he returns in no time to his spaceship from the depth of a dungeon in a faraway planet. The finite speed of our autistic facet cannot fathom the infinite speed in the artistic facet of the one-year-old girl who teases her father by handing and not handing him a tempting chocolate; of the two-year-old who pretends that a pencil is a rocket; and of the six-year-old girl who converts a "no" into a "yes" upon hearing an ironic expression.

In contrast with children's attachment to quantum infinity, classical finiteness may lead a few adult Christians to miss the fact that the second attention of the resurrected Christ helped him pass through the walls of the locked refuge of his frightened Apostles, without losing the capacity of his first attention to push into his wound the hand of the skeptical Apostle Thomas.

A deep examination of a few literary masterpieces and sacred texts intensified my claim that Mayan sages also knew 
about the artistic violation of the arrow of time (Cassella, 2016a, 2016c).

\subsection{The Violations of the Second Law of Thermodynamics in the Popol Vuh}

In the Mesoamerican sacred text Popol Vuh, for example, the Lords of the Xibalba repeatedly kill the twins Xbalanqué and Hunahpú, who resuscitate repeatedly, and face again and again the blind Xibalba tyrants in newer semblances, fashions, and ball games. Finally, their second attention helps the twins deceive their lords by convincing them that they too can revisit their palaces after being killed. The resurrection of the Lords of the Xibalba under the magic of the third attention, however, cannot follow their irreversible demise: The illusory repetitiveness adored by the Lords of the Xibalba rests only on the malevolent use of the irreversibility of the arrow of time preached by the second law of thermodynamics (Faires, 1962) in a dying world, made undying by the memory guarded within the first attention.

Shakespeare also violated the first law of thermodynamics when his third attention amused spectators by augmenting the energy of an isolated system (Faires, 1962). He did that by denying virtually the principles that drive sequential reality.

3.9 The Rise of the Reciprocal Empowerment of the Principles of the First and the Principles of the Second Attention in a Literary Masterpiece.

In Shakespeare's Merchant of Venice, Bassanio asks his friend Antonio for 3000 ducats in order to face the prenuptial riddles of the heiress Portia in Belmont. Because Antonio's ships are at sea, Shylock, a moneylender, provides the money without interest, with the condition that he would take a pound of Antonio's flesh if he missed the deadline for paying back the loan. Bassanio succeeds in solving the riddles proposed by Portia and marries her; while Nerissa, her lady-in-waiting, marries Gratian, a steady companion to Bassanio.

After the arrival of a report that Antonio's ships are lost at sea, Shylock asks the Dux of Venice to arrest the impoverished merchant. Before the judgment goes through, Portia gives Bassanio 6000 ducats to rescue his friend. The heiress and her lady-in-waiting also give a ring to the respective husband, under the promise that they would keep them no matter what. After the two friends depart for Venice, the two women go to Venice disguised as a lawyer and his apprentice.

In Venice, the angry Shylock rejects the 6000 ducats offered by Bassanio. Before the Dux is forced to witness the carving of Antonio's flesh, a word comes to him that a lawyer and his apprentice are waiting outside. When the mustachioed Portia and Nerissa enter the court of the Dux, nobody recognizes their womanhood. After Shylock refuses her offer of handing him 6000 ducats, Portia declares that the claim of the moneylender is legal. While the financier lifts happily his knife, Portia informs him that he can have a pound of Antonio's flesh, but not the smallest drop of blood - a result that would induce the death of the banker under the laws of Venice. After the Dux fines Shylock, Bassanio and Gratian are too willing to give their rings to the lawyer and his apprentice as fair compensation for saving the life of Antonio.

When they reach Belmont on the next morning, the two men see that each wife retains her original ring. They become wary when Portia asserts that she received her ring from the lawyer she slept with all night; and Nerissa, that she received it from the apprentice she embraced all night long. At that point, the minds of Bassanio and Gratian are frozen for an instant by the absolute rigidity of an unmovable location. When they see that Portia was the lawyer and Nerissa was the assistant that had faced the Dux of Venice the day before, however, the infinite speed of nonlocation in their third attention overcomes the absence of entropy posited by the third law of thermodynamics.

Along the ages, The Merchant of Venice audiences have covertly realized that the grace of Portia and Nerissa helps all characters of that Black Comedy to return to a better life in the world guarded by their first attention. The return of actors, actresses, and their audiences evokes the return of Quetzalcoatl in Mesoamerican legends.

The following Discussion examines the possibility that in the $21^{\text {st }}$ century Quetzalcoatl will return to the Earth from Venus with the secret of nature's nature, namely, the reality of the third attention. The mythical return of Quetzalcoatl in every human being, leader, and social group may help us use the perils of fundamentalism and global warming to induce a new cycle of progress.

\section{Discussion}

\subsection{The Rise of Principles that Govern Nature and the Mind}

Bassanio and Gratian smile when their third attention reveals that the second attention in their women tricked them by sharing the same space at the same time with a lawyer and his apprentice (the quantum principle of coincidence in logos) and by existing simultaneously in Belmont and in Venice (the quantum principle of ubiquity) (see Figure 4). 


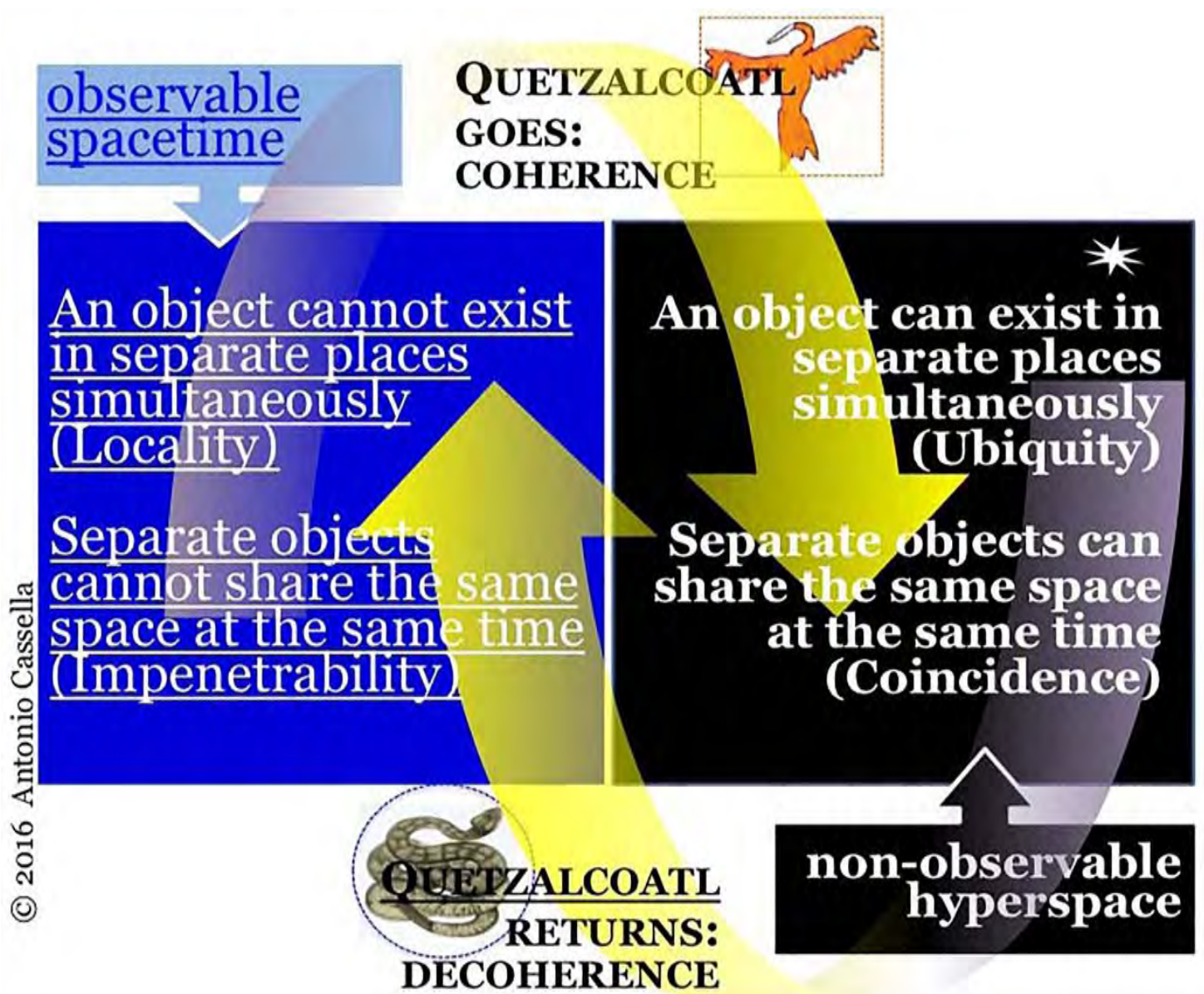

Figure 4. A view of the principles of spacetime and hyperspace

I compare the principle of ubiquity to quantum entanglement; the principle of coincidence, to quantum superposition; and the principle of impenetrability, to Pauli's exclusion principle. My principle of locality has no corresponding avatar in quantum physics. Our patience, when we smile in front of mutually exclusive pieces of information or when criticism does not upset us, can be related to the simultaneous worthiness of position and momentum in Heisenberg's indeterminacy principle (Icke, 1995) and to the implicit complementarity of the principles of spacetime with the principles of hyperspace in the decoherence appreciated by Niels Bohr (Cassella, 2016a). (The image of the serpent is in the public domain,

Conversely, the classical principle of locality stresses in logos that an object cannot exist in separate places simultaneously; and the classical principle of impenetrability, that separate objects cannot occupy the same space at the same time.

In safely crossing an intersection ruled by a yellow traffic light, for example, the principles of ubiquity and coincidence in our quantum senses readjust the principles of locality and impenetrability in our classical senses. As with Heisenberg's indeterminacy principle and the decoherence appreciated by Niels Bohr (Icke, 1995), the quantum indeterminacy suddenly unleashed by a yellow traffic light toward green-light observers is coupled to the alleged certainty conveyed by classical neural computing to red-light observers. Quantum neural computing in sober drivers, however, must remain vigilant, since an inebriated motorist may disrespect simultaneously the classical rule inherent in stopping at a red light and passing with a green light and the quantum rule that invokes prudence in the context of a yellow light; and even of a green light! As with drunk drivers, imprudent leaders cannot refrain their mouth from chirping their disrespectful hatred toward whoever or whatever displeases their overcooked knowledge or their diabolical agenda.

Prudence in the drivers that slow down before an intersection blessed by a green light demonstrates why the autisticlike relativity of simultaneity invoked by Einstein in spacetime may change into the artistic simultaneity of relativity introduced by hyperspace (Cassella, 2016a). Similarly, the uncertainty unleashed by Shakespeare in The Merchant of Venice suggests that the principles of the first attention and the principles of the second attention support one another. 
This occurs when we step on the inner devil that haunts coherence, in order to return through decoherence to the certainty of a renovated familiar world. In The Merchant of Venice, the patience of Bassanio and Gratian joins the love of Portia and Nerissa in defeating the bloodthirsty devil hidden in quantum coherence and in jumping elegantly into the quantum-decoherence phase that saves the friendship between the two couples and the gratification of the audiences of Shakespeare's humanistic creativity. Patience and love can realize in today's visible reality the friendly return of the Mesoamerican demigod Quetzalcoatl to his pyramid in Teotihuacan.

\subsection{The Surrender of the Devil in Mesoamerican and Syriac Ancient Mysticism}

When a small group of Mexica mercenaries entered the Valley of Mexico in the $13^{\text {th }}$ century CE (Common Era), they saw the Pyramid of the Sun, the Pyramid of the Moon, and the Pyramid of Quetzal-coatl (or bird-serpent in the Nahuatl language of the Aztecs that merged the Mexicas, the Acolhuas, and the Tepanecs) in the city of Teotihuacan, which had been abandoned about 700 years before.

A few Toltec sages told the Mexica warriors that the three abandoned pyramids pointed to the voyage of Quetzalcoatl to Venus and to his eventual return. However, the strife-prone Mexicas grasped neither the malevolent meaning of Quetzalcoatl's ascent to planet Venus on the ramp of hyperspace through quantum coherence (at the left of Figure 5) nor the benevolent meaning of his descent onto Earth after decoherence (at the right of Figure 5).

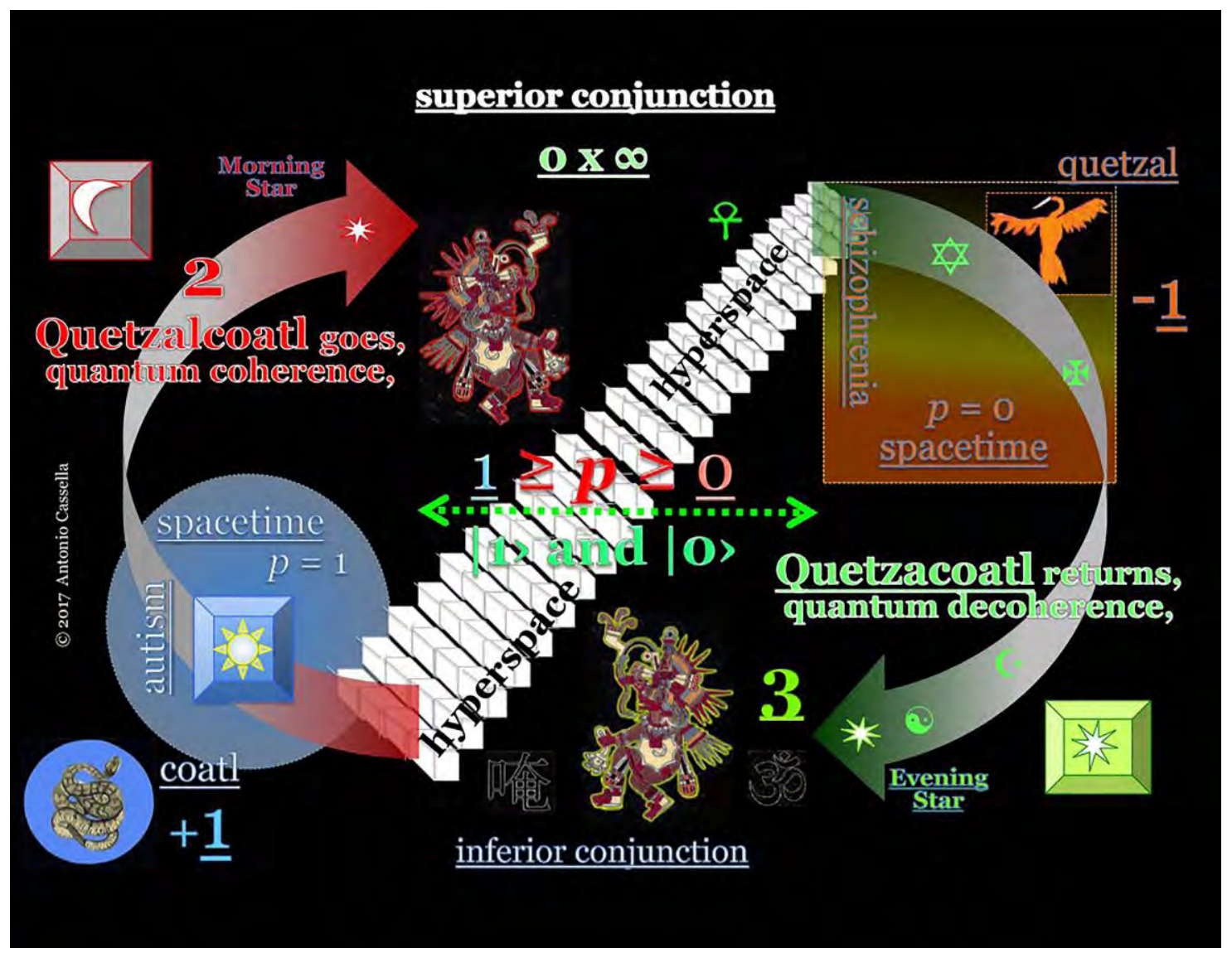

Figure 5. Coherence and decoherence in the going and coming of Quetzalcoatl

After leaving the known reality of the coatl $(p=$ probability $=+1)$ behind, Quetzalcoatl ascends the ramp of hyperspace with the Morning Star (2, in which $1 \geq p \geq 0$, or $p=|1\rangle$ and $|0\rangle$ [ket one and ket 0 ]). If he escapes the madness of the quetzal ( $p=0$ ), Quetzalcoatl will descend the metaphorical ramp of hyperspace with the Evening Star and return (3) to his (green) pyramid. (The pictures of the serpent and of Quetzalcoatl are in the public domain, .)

As with the Aztecs' ignorance of the diabolical and the angelical aspects of hyperspace, rigid readers of the Torah and the Bible do not easily associate Jacob's dream of the ramp of hyperspace in Bethel with the possibility of renewing the integrity of a family, a town, or a country, instead of precipitating its disintegration.

Figure 6 shows the synodic cycle that highlights the going of Quetzalcoatl to Venus with the Morning Star and his return to the Earth with the Evening Star. I associate quantum coherence to the works of the devil and to the vain alliance of the Sun-god Huitzilopochtli with the Moon-Coyolxauhqui. The use of terror to control their enemies, for 
example, prevented the Aztecs from using the quantum malice hidden in the departure of Quetzalcoatl to Venus.

Unlike the Aztecs, the Spanish "Conquistador" Hernán Cortés annihilated their capital city—Tenochtitlan —and their ruler Moctezuma II because his mischievousness knew about the fundamentals of the treason brought by quantum coherence. Both Cortés and Moctezuma II ignored the redeeming play of the return of Quetzalcoatl through quantum decoherence and the Evening Star.

In the $17^{\text {th }}$ century, the Mexican Sor Juana Inés de la Cruz separated her way from the way of the Aztecs and the way of the Spanish "Conquistadores" when she died helping others hit by the plague. The portrait of Juana Inés de la Cruz in Figure 6 suggests that the third attention awakens in us when we disown Faust by matching the Virgin of Guadalupe in stepping with grace over the moon that animates the diabolical Mephistopheles.

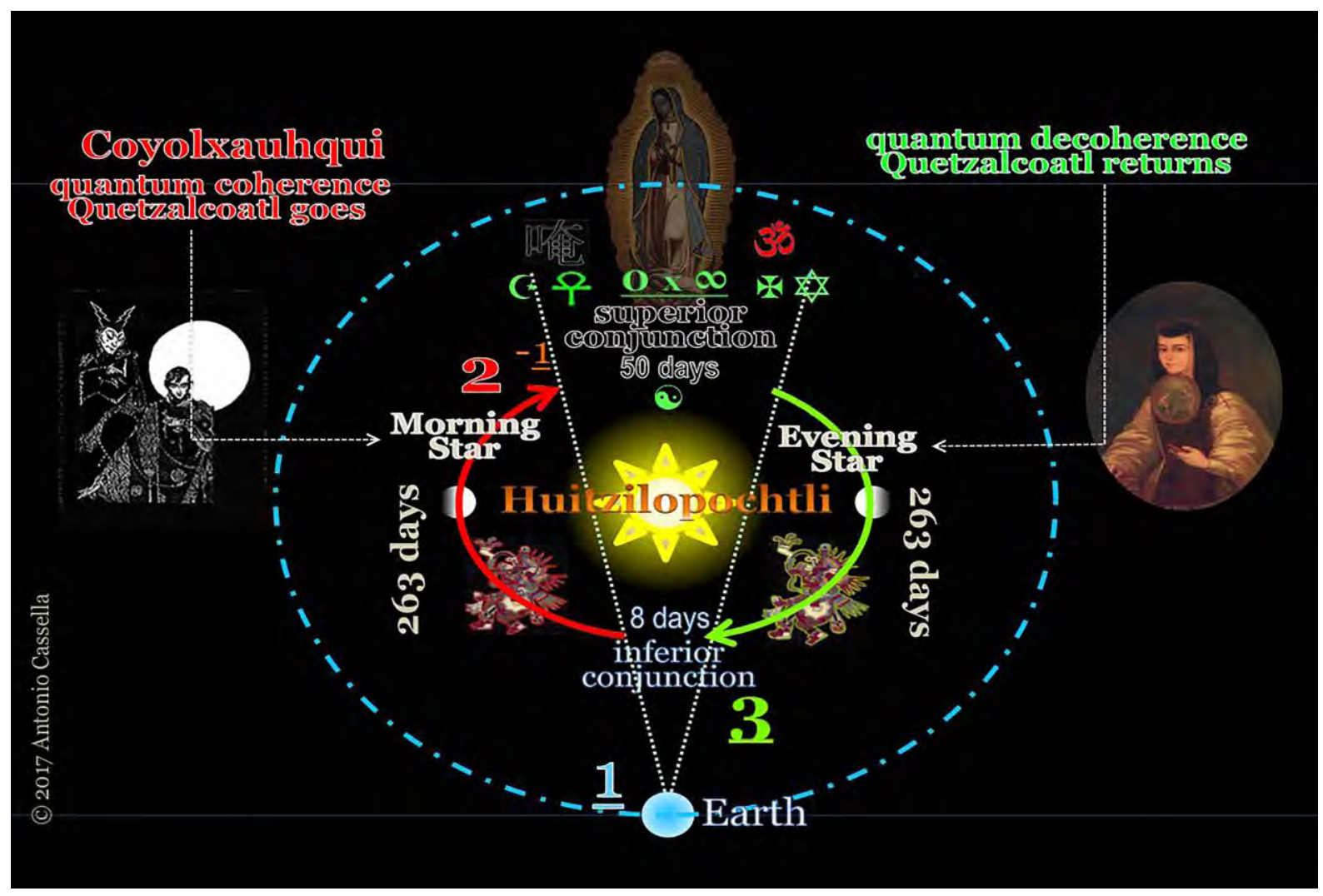

Figure 6. The departure of Quetzalcoatl within coherence and his return under decoherence

As with the bearded "Conquistador" Hernán Cortés, the Quetzalcoatl that goes with quantum coherence and the second attention is filled with malice and ambition, whereas the Quetzalcoatl that returns with quantum decoherence and the secret of the third attention is filled with grace and love. (The images of the Devil, Faust, the Virgin of Guadalupe, and Sor Juana Inés de la Cruz are in the public domain,

The Prophet Muhammad, for example, stepped on his inner quantum devil at the end of quantum coherence when his al-Isra journey allowed him to reach the ambiguous infinity inherent in the farthest Mosque and the Morning Star. He also met decoherence and the Evening Star when his al-Miraj journey allowed him to cross hell and paradise before returning to the Black Stone in Mecca by the infinite speed enclosed in a quantum night.

Jesus had courted the darkness of infinity about six centuries before, when he climbed Mount Tabor. ${ }^{3}$ The Apostle Peter's suggestion to erect three tents there - one for Moses as the first attention, one for Elijah as the second attention, and one for Jesus as the third attention — reflects the spontaneous conversation among Jesus, Elijah, and Moses.

The third attention of the tortured Christ came true when He refused to use the infinite speed of ubiquity and the nothingness of coincidence to escape crucifixion. He submitted willfully to the principles of locality and impenetrability in the nails that nailed Him to the cross that disgruntled Roman soldiers had nailed on the top of Mount Golgotha, where classical ascent and classical descent cross each other in a quantum intersection.

${ }^{3}$ In the view of Origenes. 
The arithmetical zero implied by the top of a mountain, by the top of a pin, or by the intersection of different straight lines may become a metaphor for the apparition of dancing angels, the Archangel Gabriel, and our victory over anger, arrogance, and wanton temptations. For example, the concern of Duns Scotus and Thomas Aquinas about how many angels can dance on the head of a pin does not embrace stupidity or madness in the first attention (Cassella, 2016a). These two scholastic philosophers justly worried about the embrace $(0 \mathrm{x} \infty)$ of transcendental nothingness in quantum coincidence with the infinite speed pursued by quantum ubiquity in the second attention.

\subsection{Winning with the Nothingness of Quantum Superposition and the Infinite Speed of Quantum Entanglement}

The quantum hurricane going from left to right in Figure 7 suggests that quantum entanglement (or the capacity for leaving stupidity behind with the infinite speed [ळ] that dwells in two worlds simultaneously) and quantum superposition (or the capacity for leaving madness behind by sharing the same space with something else at the same time [0]) may embrace each other ( $\infty$ x 0). One example from popular culture is Batman's quantum jump when he understands a riddle presented by the devilish Riddler.

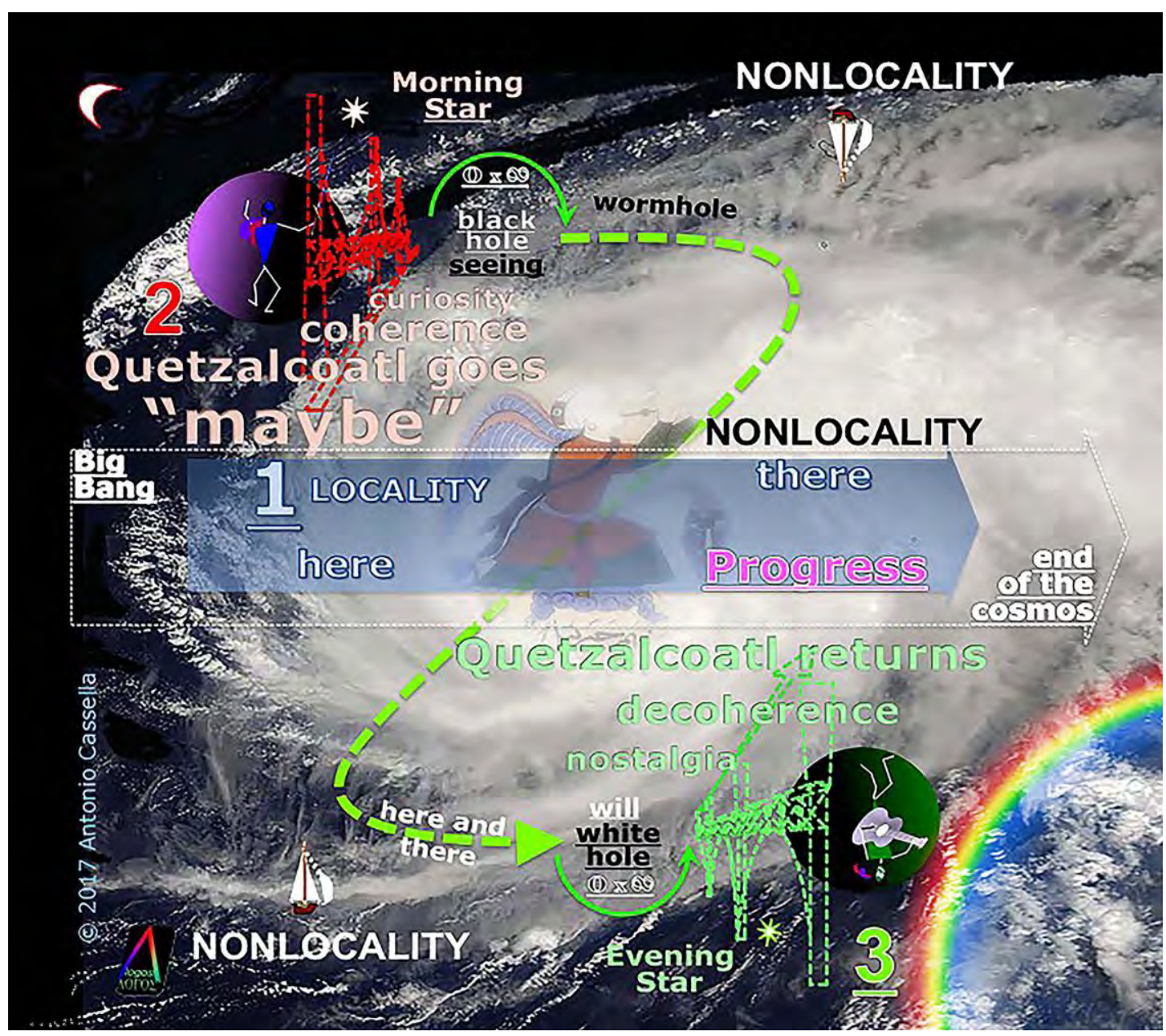

Figure 7. The quantum trumpet of the Archangel Gabriel in the Bible and the Quran

The infinite speed that allows us to pass from seeing to will inside a wormhole will help us save the self and the other. (The images of the Archangel Gabriel and of the hurricane are in the public domain, $\$$ )

We return to the illusory familiar world when the trumpet of the Archangel Gabriel forces our inner devil to surrender to our inner grace, reveals a humanistic vision (seeing) of reality, and invites us to change (will) the world, in order to benefit ourselves by benefiting our opponents. For example, while the Archangel Gabriel fought Jacob in Penuel, he realized that that shepherd had used his quantum capacity for lying to win with his father-in-law, Laban. Hence, God's messenger changed Jacob's name to Israel. ${ }^{4}$

\footnotetext{
${ }^{4}$ A deeper explanation can be found in Cassella (2016a).
} 
As with Israel, when an altruistic will follows an altruistic seeing, we will cross the wormhole that joins the black hole $(0$ $\mathrm{x} \infty)$ after the bridge of coherence $(1 / 0=\infty)$ with the white hole $(\infty \mathrm{x} 0)$ before the bridge of decoherence $(0 \mathrm{x} \infty=1)$. In mathematical and mystical terms, when we step over the devil that haunts quantum coherence at the edge of lunacy, arithmetical zero changes into transcendental zero, transcendental zero embraces transcendental infinite $(0 \mathrm{x} \infty)$, and seeing embraces will.

As Saint Francis of Assisi implied in the Canticle of the Sun-and Sor Juana Inés de la Cruz in The Dream, the quantum hostility introduced by our inner devil changes into the friendship brought by the third attention. By contrast, we obliterate the beautiful when we steal our daily bread by riding a big SUV, abandoning a broken toy on a beach, throwing a plastic bag in the ocean, or releasing harmful chemicals into the wind, the soil, and natural aquifers.

Figure 8 demonstrates the beauty hidden in the nine verses of the Lord's Prayer and in two verses from the Quran:

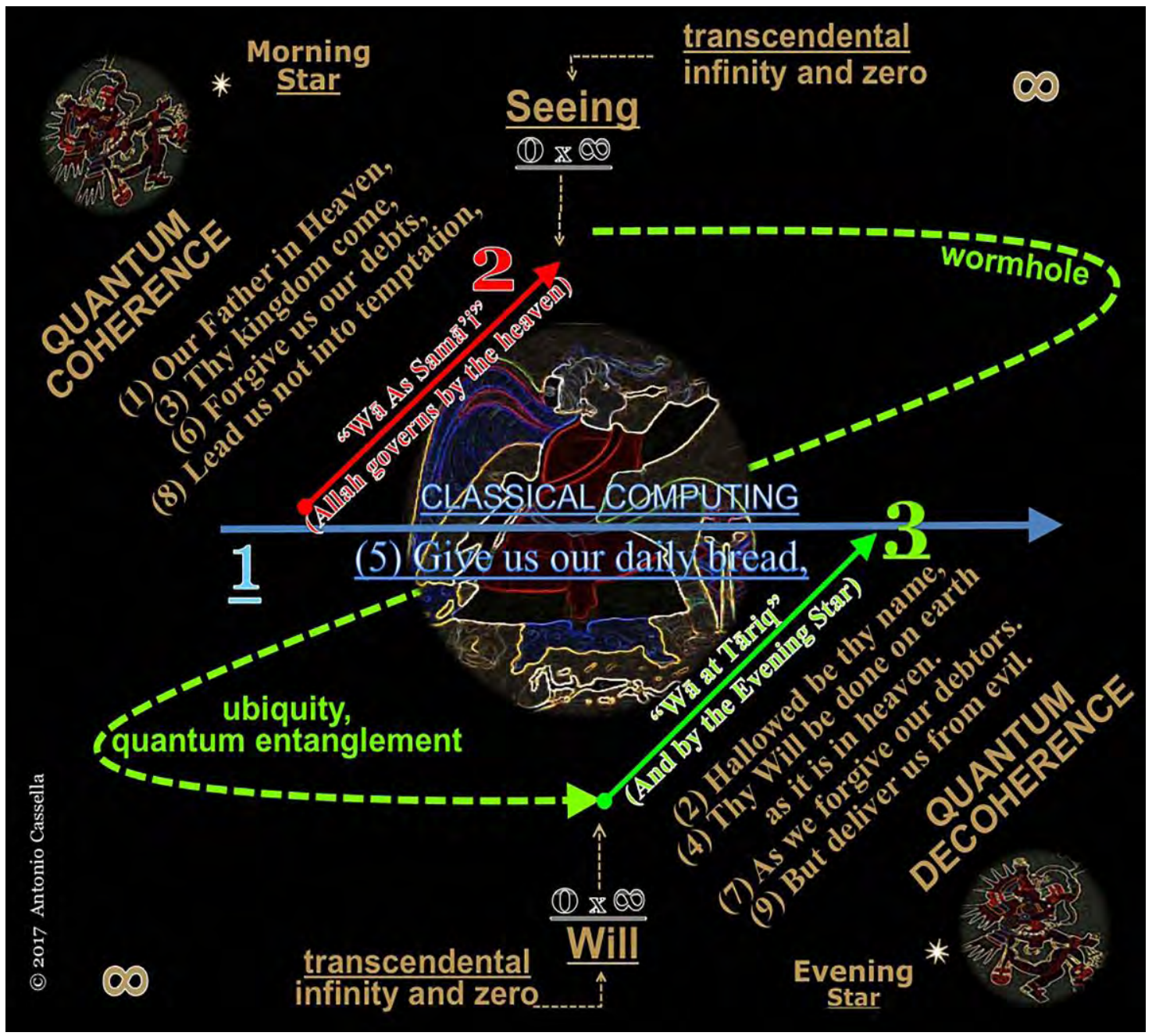

Figure 8. The embrace of classical and quantum computing in the Lord's Prayer and in the friendship of Allah

Invisible information processing in quantum coherence and decoherence readjusts visible information processing in classical reality. (All subsidiary images are in the public domain, For example, verse three of the Lord's Prayer, "Thy Kingdom come" (quantum coherence at left) and verse four, "Thy Will be done on earth as it is in heaven" (quantum decoherence at right) precede verse 5, "Give us our daily bread" in the classical computing that sustains visible spacetime.

In spacetime we may steal what we want, as does Faust by seeking the alliance of the Mephistopheles that animates the going Quetzalcoatl; or we may take what others and God give us, as did Sor Juana Inés de la Cruz with the returning Quetzalcoatl.

Figure 8 also stresses the grace of two verses of the Quran (86:1): "Wā As-Samā'i" ("Allah governs by the heaven") (quantum coherence), "Wā at-Tāriq" ("and by the star that shines first at night") (quantum decoherence). 


\subsection{The Four Facets of the Self}

Figure 9 proposes that the third attention revives the mind of any reader:

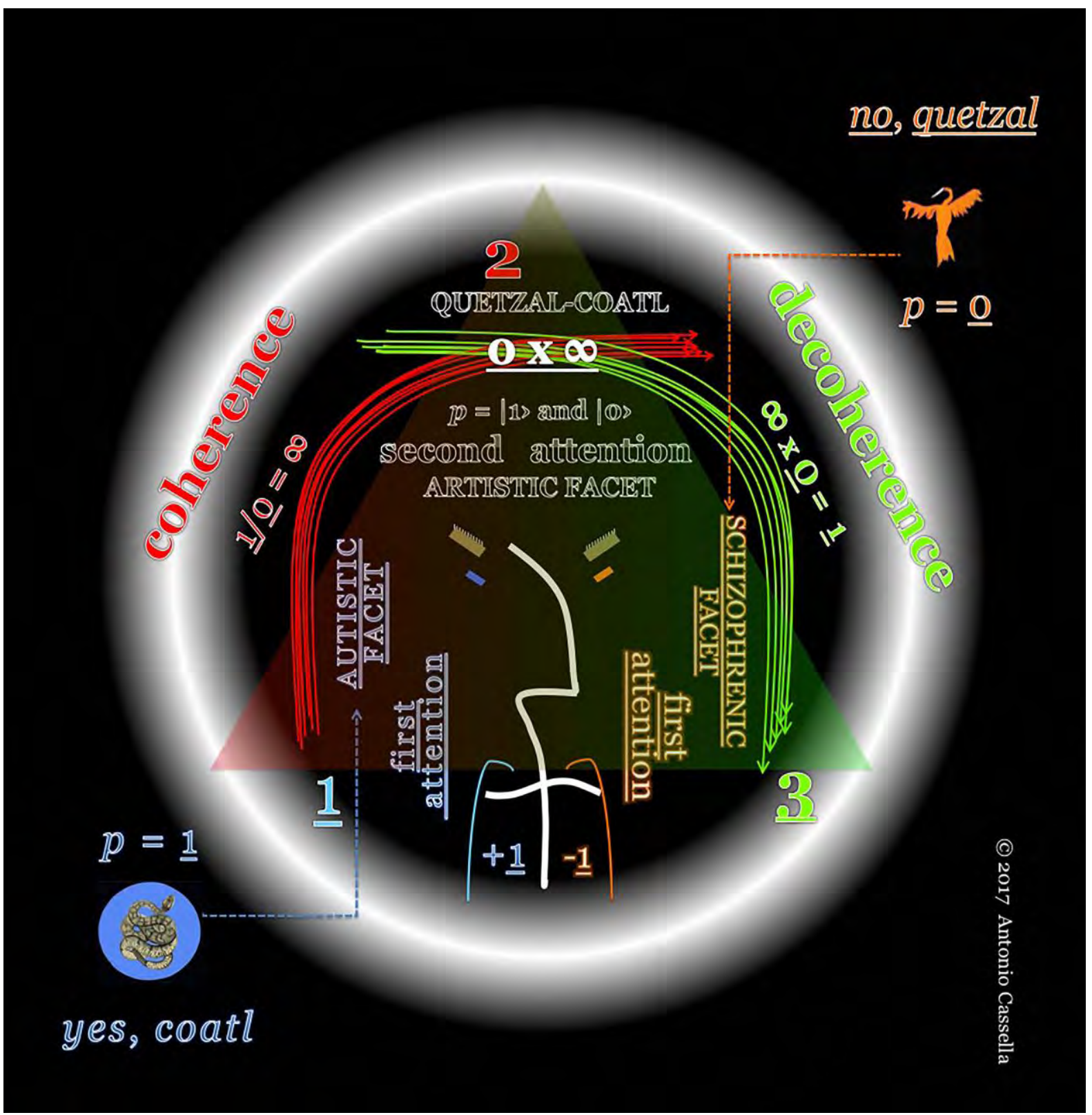

Figure 9 . The four facets of the self

On the one hand, the first attention of autistics (yes, coatl, $p=$ probability $=1$ ) precludes them from listening to the temptations in quantum coherence, symbolized by the red hair ( $|1\rangle$ and $|0\rangle$, or ket one and ket zero). On the other hand, schizophrenics (no, quetzal, $p=0$ ) cannot seek the deliverance from evil in quantum decoherence, under the green hair (also $|1\rangle$ and $|0\rangle$ ). Within the second attention, autistics cannot depart, whereas schizophrenics cannot return. (The image of the serpent is in the public domain,

Seeing the three facets of the self simultaneously, as if they made a fourth face (3), equates the return of Quetzalcoatl to grasping the essence of social values.

\subsection{The Essence of Social Values}

By crossing the presence and the absence of autistic respect (Hovalim or Thummim in the two vertical columns) with the presence and the absence of artistic talent (No'am or Urim in the two horizontal rows), Figure 10 substantiates four hypothetical visions of social values: 


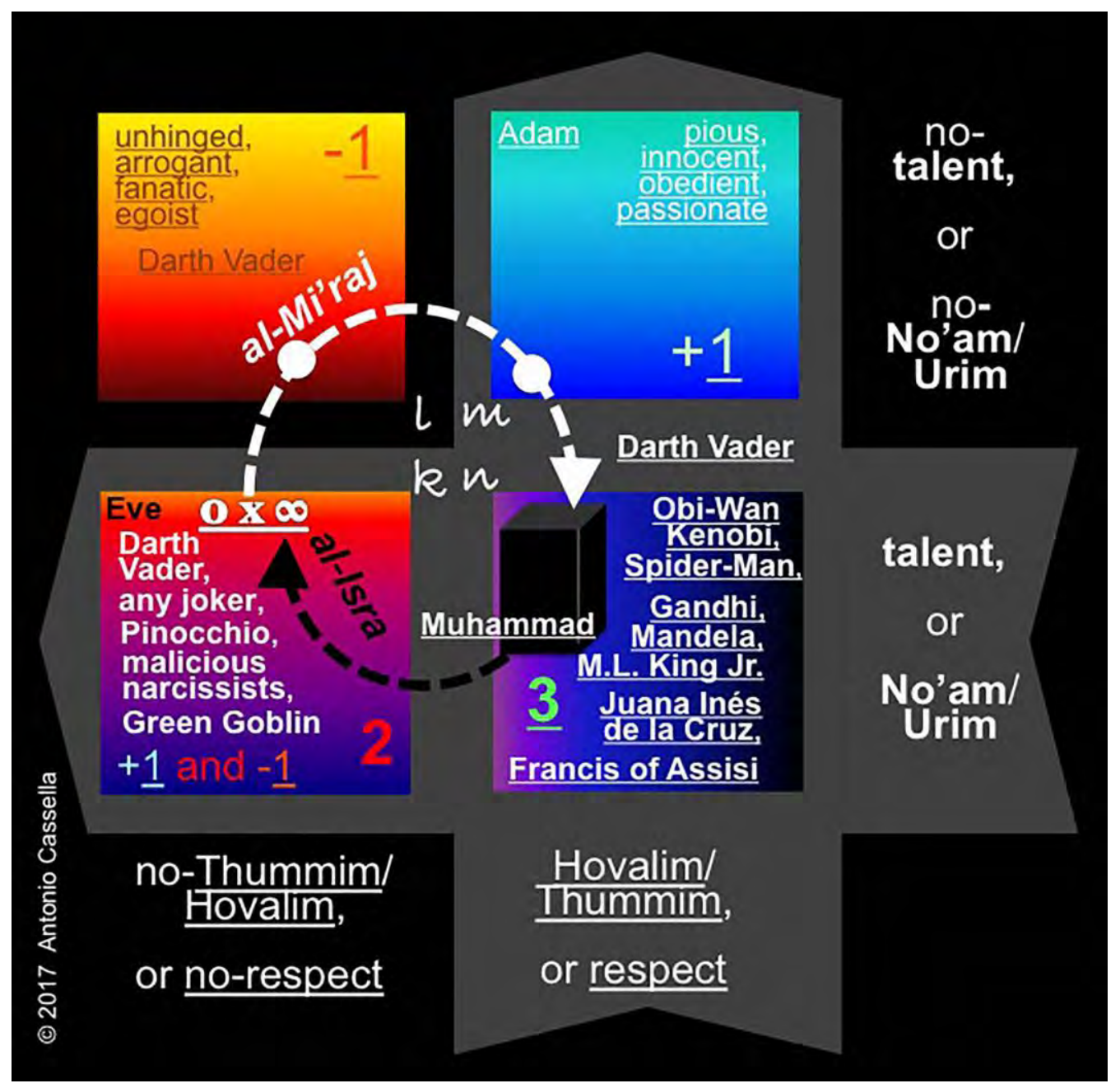

Figure 10. The highs and lows of social values

Few of us follow the characters Obi-Wan Kenobi and Spider-Man in staying forever in quadrant "n." Although the meanest among us will appreciate the ways of the Green Goblin in quadrant "k," the voyage of Muhammad from Mecca to the Farthest Mosque and back demonstrates that before dying we can all return to the roots of social intelligence in quadrant " $n$," in which we were all born.

Infinite speed in the coherence lodged in quadrant "k," at the lower left of Figure 10, greets the end of Muhammad's al-Isra journey into the Farthest Mosque, whereas multiplying infinite speed by transcendental zero $(\infty \mathrm{x} 0)$ allowed the Prophet to jump from his going al-Isra into his returning al-Mi'raj flight.

At the upper left corner of Figure 10, quadrant "l" greets the hellish stop in Muhammad's returning trip, the arrogant that does not accept criticism, the fanatic, the egoist, and any leader who finds an enemy that he cannot defeat.

At the upper right corner of Figure 10, the autistic paradise of quadrant "m" encloses the heavenly stop in Muhammad's return to Mecca, the rigid rites cherished by Kong Fuzi (Confucius), the heavenly wants of brainwashed fundamentalists, and the last words of Darth Vader to his son before dying.

Finally, quadrant "n" welcomes the repented Darth Vader; Spider-Man; Gautama Buddha; Gandhi; Nelson Mandela; Dr. Martin Luther King Jr.; the returning Prophet, the Bodhisattvas that induce the blooming of kindness in others; heroes and heroines; the visit to his Apostles by the resuscitated Christ; Pinocchio's gain of flesh and blood; the return of Rama, Sita, and Arjuna; the arrival of Laozi from the "place of no-return" (the "Taklamakan" desert); the humbleness of Saint Francis, the humanistic genius of Sor Juana Inés de la Cruz, and Quetzalcoatl's return to Earth with the secret of the third attention.

If we join our artistic talent and our autistic respect to an understanding of social values and to our scientific know-how, we will overcome terrorism and global warming. As with the walls of Jericho, however, any leader and any anthropic 
organization that cannot cross talent with respect (quadrant " $n$ " in Figure 10) "will come tumblin' down."

\subsection{The Onset of Anthropic Global Warming}

I begin my analysis of the effects of global warming by presenting four assessments:

a) One half of the total recoverable volume of fossil resources on Earth-60-70 $\times 10^{12}$ barrels of oil equivalent (BOE) - is composed of dirty coal and lignite; 30\% consists of crystals of methane clathrate ${ }^{5}$; and the remaining 20\% corresponds to conventional oil, heavy oil, bitumen, and gas (Cassella, 2008, 2016a).

b) 7.5 billion people today use the energy enclosed in 260 million barrels of oil equivalent per day (MBOPD), of which approximately $75 \%$ come from the exploitation of coal, oil, and natural gas (BP, 2016).

c) If we divide the amount of proved fossil reserves $\left(7.44 \times 10^{12} \mathrm{BOE}\right)$ by the annual and actual consumption $\left(0.07 \times 10^{12} \mathrm{BOE}\right)$, we will obtain 106 years.

d) However, if we continue to simultaneously increase global population and the per-capita consumption of energy while forfeiting an extraordinary effort to boost green energy, the consumption of fossil resources would triple before the end of the $21^{\text {st }}$ century (Cassella, 2008, 2016a).

Because fossil resources surpass proved reserves by ten times, it would seem that the problem of the future scarcity of fossil energy could be left to our great-grandchildren. The real problem, however, it that our great-grandchildren will have no future unless we produce more green energy and deal creatively with the green gases unleashed by a growing population and per-capita energy consumption. A view of the past explains why. Figure 11 offers important clues about the variables related to climate upheavals in the last 650000 years:

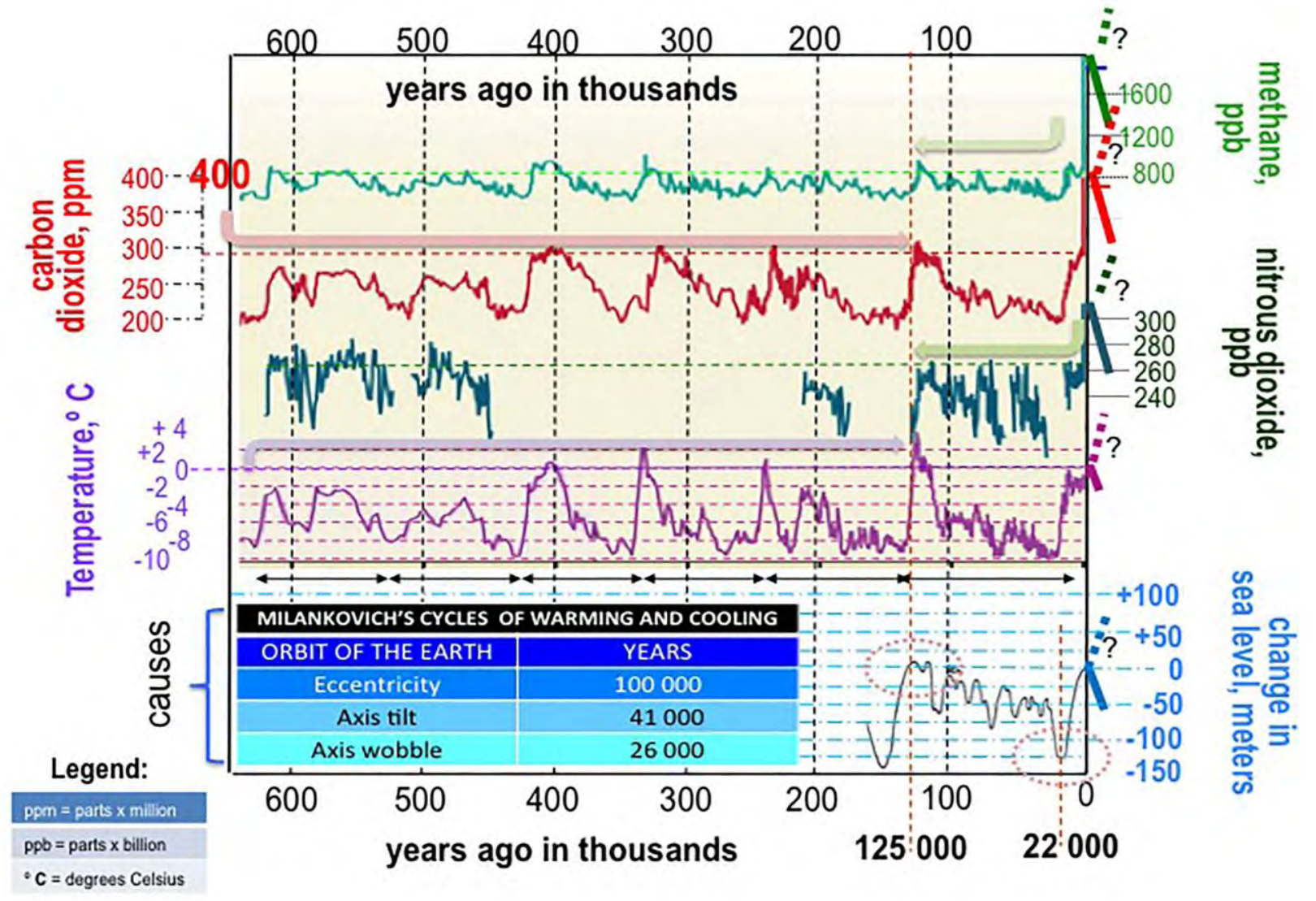

Figure 11. Levels of greenhouse gases in the last 650000 years and level of the sea in the last 140000 years

During the last 650000 years, changes in average temperature of the lower atmosphere, in its content of carbon dioxide, methane, and nitrous oxides, and in the level of the sea have followed each other. The curves in this chart combine data

\footnotetext{
${ }^{5}$ Methane clathrate is a methane hydrate, or a molecular ice crystal consisting of a methane molecule surrounded by a water-ice structure. When the pressure is lowered and/or the temperature increases, the clathrate at the bottom of some seas releases the methane trapped by the water molecule.
} 
about greenhouse gases offered in the Fourth Report of IPCC (2007) (@). I drew the data on sea level until 22000 years ago from a curve prepared by NOAA in 2006. Although NOAA's work on the variation of sea level agrees with Miller's work (accessed in 2017), I trusted fully the research tapped by Gornitz (2012) and Ruppert (2014) to adjust average sea levels in the past 22000 years.

The variation of sea level, or eustasy, in the past 140000 years agrees strongly with the variation of the average temperature of the atmosphere at sea level-a frightening fact. As I said in the Background, 125000 years ago, the average temperature of the atmosphere was $3^{\circ} \mathrm{C}$ above present values; sea levels were seven meters higher than present-day levels.

In the near past, the variation of sea level can be linked to the melting of the great ice sheets in the Northern Hemisphere and of Antarctic glaciers. In the far past, the intrusion of tectonics and the release of greenhouse gases from natural sinks introduce deep uncertainties.

The natural variation of solar forcing unleashed purgatory in the life of Neanderthal humans about 140000 years ago. Global warming induced in the $21^{\text {st }}$ century by "Homo insipiens" ("senseless Man") will unleash hell. Indeed, the 100-years difference between the rise of the temperature of the lower atmosphere and the level of the sea will cause the relentless melting of the ice trapped on land above sea level in Greenland and Antarctica. Low-level islands will be submerged; coastal cities will be dislocated; and the life span of our great-grandchildren will be shortened.

\subsection{The Rise of Hell on Earth}

Figure 12 supports my hypothesis on the mechanism of an environmental eruption:

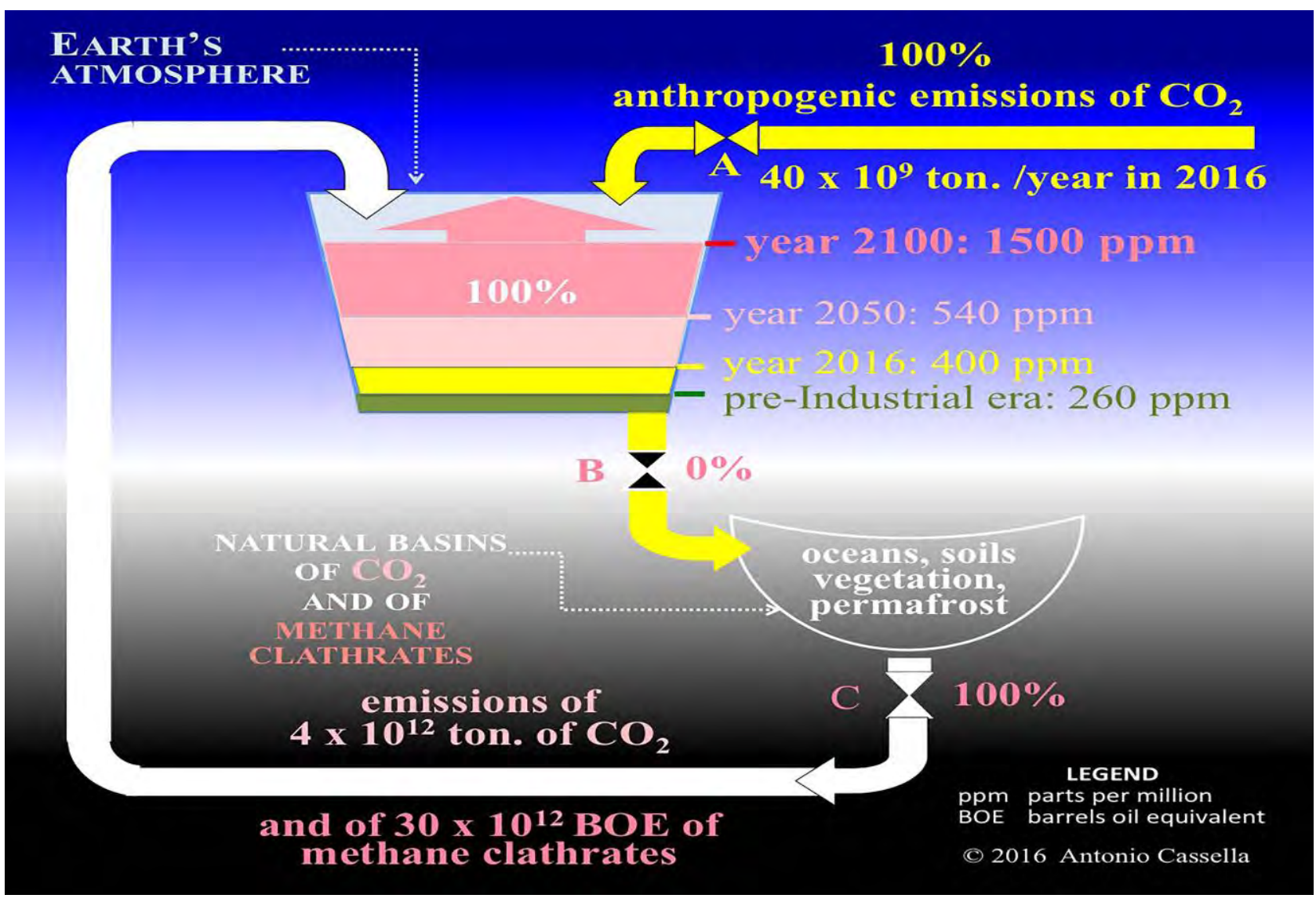

Figure 12. Sketch of an environmental eruption at the turn of the $21^{\text {st }}$ century

The closing of virtual valve $\mathrm{B}$ and the opening of virtual valve $\mathrm{C}$ would release the greenhouse gases trapped in natural sinks.

My assessment of the incipient global warming revolves around four scenarios (Cassella, 20 16a):

A. In the first "Mitigation" scenario, the concentration of $\mathrm{CO}_{2}$ does not surpass $600 \mathrm{ppm}$ at the end of the $21^{\text {st }}$ century, the average surface temperature of the Earth does not increase beyond $2^{\circ} \mathrm{C}$ (degrees Celsius), and sea level only rises by two meters. The eventual leaks of methane from deep storage and gas pipelines invalidate this 
scenario - for example, the methane leak caused in late 2015 and early 2016 by well SS25, in Aliso Canyon (CA).

B. In the "All-rich" scenario, 83 years from now the average temperature of the atmosphere on Earth increases by $3^{\circ}$ $\mathrm{C}$, the corresponding concentration of $\mathrm{CO}_{2}$ will surpass $800 \mathrm{ppm}$, virtual valve $\mathrm{B}$ will continue to close, and virtual valve $\mathrm{C}$ will start opening (Figures 2 and 12). Sea level will rise by 7 meters only.

C. In the third, "Inferno" scenario, the atmospheric concentration of $\mathrm{CO}_{2}$ will reach $1300 \mathrm{ppm}$ at the turn of the $21^{\text {st }}$ century, the average surface temperature of the atmosphere will rise by $6^{\circ} \mathrm{C}$, virtual valve $\mathrm{B}$ will close, virtual valve $\mathrm{C}$ (Figure 12) will open completely, and $4 \times 10^{12}$ tons of $\mathrm{CO}_{2}$ and $30 \times 10^{12} \mathrm{BOE}$ (barrels of oil equivalent) of methane will be released into Earth's atmosphere. The proverbial elephant in a china shop will cause a rise in the level of the sea of about 70 meters in 10000 , in 500 years, or in a shorter time span.

D. Finally, in the "Armageddon" scenario, the atmospheric concentration of $\mathrm{CO}_{2}$ will surpass 1500 ppm, the surface temperature of the atmosphere will increase by $8^{\circ} \mathrm{C}$, and dissolved hydrogen sulfide will bubble out of solution from the sea. The ozone layer would be drastically hit, and an environmental catastrophe-unseen since the Permian Era, 300 million years ago (Ward, 2006) —would erase civilization and most species.

Present leaders can avoid untold suffering by marrying an understanding of social values with our unprecedented scientific and technological skills. However, since there is always the possibility that my hypotheses may be incorrect, I close the Discussion with a humanistic example of a contentious hypothesis that can be easily falsified.

\subsection{Exploring the Mystery of the Location of the Lost Mural Battaglia di Anghiari by Leonardo da Vinci}

In 1505, the young painter Raffaello Sanzio may have seen Leonardo da Vinci painting his vanished Battaglia di Anghiari on the east wall of the first Hall of the Five Hundred at Palazzo Vecchio in Florence (Figure 13).

In a previous article (Cassella, 2016b), I explain that Leonardo followed a drying technique suggested by Pliny the Elder in the encyclopedia that he polished at night in the autumn of his life, before meeting Emperor Vespasian at dawn. Before dying in $79 \mathrm{CE}$ in the eruption of Mount Vesuvius that destroyed the cities of Pompeii and Herculaneum, Pliny wrote that the Roman technique to dry scenes painted with pigments diluted in nut oil ("encaust") had to be applied to paintings that were extended on a floor. Because Leonardo did not understand Latin, he failed to preserve the upper part of his mural.

An unknown biographer in the Anonimo Gaddiano (16th century, fol. 121. Cod. Magliab. XVII, Biblioteca Centrale di Firenze) wrote:

“. . . et di Plinio cavò quello stuccho con il quale coloriva, ma non l'intese bene ... poj la volse mettere in opera nella Sala, do ve giù basso il fuoco agiunse et seccholla, ma lassù alto, per la distantia grande non vi aggiunse il calore et colò" (" ... and from Pliny he took the encaust with which he colored, but he did not understand it well ... after that he wanted to implement it in the Hall, where in the lower part the fire dried it: but in the highest part, due to the great distance, there was no addition of heat and it ran down"). ${ }^{6}$

By the end of 2011, a research team directed by Maurizio Seracini failed to find da Vinci's Battaglia di Anghiari in the newer Hall of the Five Hundred behind the painting Battaglia di Marciano in Val di Chiana by Giorgio Vasari. However, the research team did find remains of pigments that Leonardo may have used on the mural in question and in other paintings. That exploration was motivated by the words "CERCA TROVA," painted on a banner on the losing side in the upper part of the Battaglia di Marciano. The existence of several copies of the Battaglia di Anghiari and the fact, stressed by Seracini, that no artist but Vasari touched the eastern wall of the Hall after Leonardo, suggest that the lesser damaged part of Leonardo's Battaglia di Anghiari remains concealed in that hall.

Until three months ago I believed (Cassella, 2016b) that Vasari himself wrote the words "CERCA TROVA"; that Cosimo I (the Medici who ruled Florence when Giorgio Vasari modified the Hall) did not like the tribute to a battle won by the Republic of Florence; that the painter lodged in Vasari secretively made a realistic copy of the damaged Battaglia di Anghiari with an aim to destroying it in front of Cosimo I; and that the architect hidden in the former preserved Leonardo's mural under that nose of the latter-perhaps in an interspace behind the interspace explored by National Geographic through Maurizio Seracini.

At present, reliable information that the words "CERCA TROVA" feed a red herring or a different meaning than the one I believed until a few months ago has led me to hypothesize that the mural Battaglia di Anghiari lies hidden under and not behind Vasari's painting Battaglia di Marciano. In Figure 13 I present my readjusted null hypothesis and an alternate hypothesis:

\footnotetext{
${ }^{6} \mathrm{My}$ translation and emphasis in italics.
} 


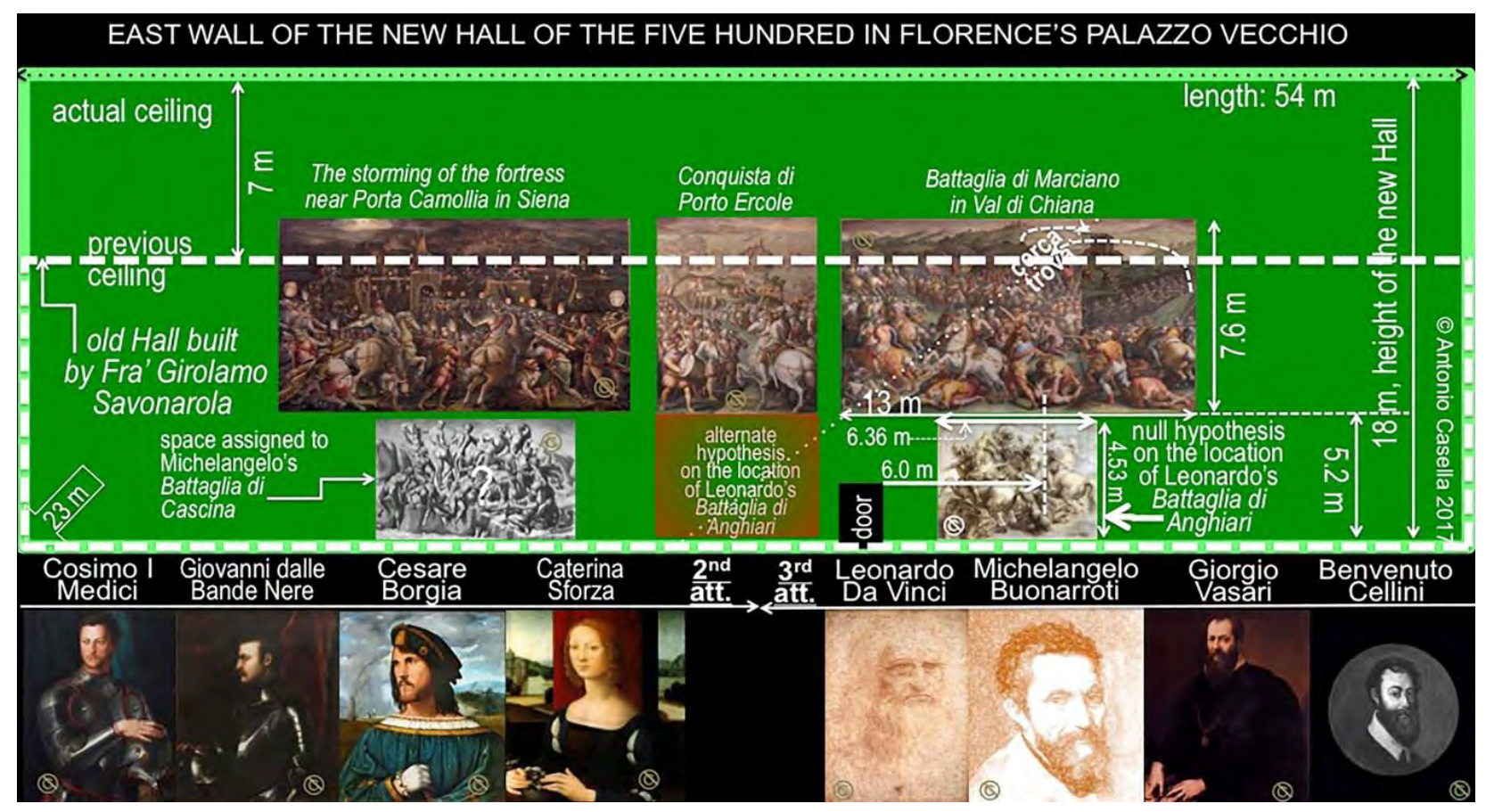

Figure 13. Sketch of the location of the mural Battaglia di Anghiari in the Hall of the Five Hundred at Palazzo Vecchio in Florence

A probing hole could be drilled in a southern direction, about six meters from the right top corner of the door located under Vasari's Battaglia di Marciano in Val di Chiana. The open mouth of a soldier being murdered on the soil of Vasari's Battaglia di Marciano can be connected truthfully to the open mouth of a soldier being murdered on the soil of Leonardo's Battaglia di Anghiari. At the bottom left, the portraits of four representatives of the diabolical use of the second attention are included; and at the bottom right, the portraits of four representatives of the humanistic vein of the third attention are included.

The seemingly disparate reasons for locating the lost Battaglia di Anghiari under Vasari's painting Battaglia di Marciano are:

a) Vasari could not deceive Cosimo I (the latter was the son of the Condottiere Giovanni dalle Bande Nere and the grandson of Caterina Sforza, a Condottiera who survived the infinite malice of Cesare Borgia);

b) Caterina Sforza admired Girolamo Savonarola, the Dominican monk that envisioned the construction of the Hall of the Five Hundred;

c) Cosimo I protected artists like Giorgio Vasari, Benvenuto Cellini, and Michelangelo;

d) If the tyrant agreed to preserve the upper part of Leonardo's Battaglia di Anghiari, he certainly agreed to preserve the lower part;

e) Vasari would not paint his Battaglia di Marciano in front of Leonardo's masterpiece;

f) Cosimo I ordered the elevation of the Hall by 13 "braccia" (about seven meters) to protect Leonardo's wo rk;

g) The particles of dust that exit up from an unexplored hole in the lower part of the interspace searched by Seracini point at the existence of a separation between two walls under Vasari's Battaglia di Marciano;

h) Leonardo's less damaged portion of his Battaglia di Anghiari would lie where abundant heat preserved it—in the bottom part of the eastern wall;

i) The open mouth of the soldier being murdered on the soil of the Battaglia di Marciano cues straightforwardly the open mouth of the soldier being murdered on the soil of the Battaglia di Anghiari.

An alternative hypothesis places the Battaglia di Anghiari under the painting Conquista di Porto Ercole.

Figure 13 depicts my two falsifiable hypotheses. Inserting a probe into a hole about six meters south of the right top corner of the frame of the door in the eastern wall would require no scaffolding, would convey a meager expense, and would not compromise the integrity of Vasari's work. 
Figure 14 shows a close up of five elements of the relationship between Leonardo's and Vasari's works.

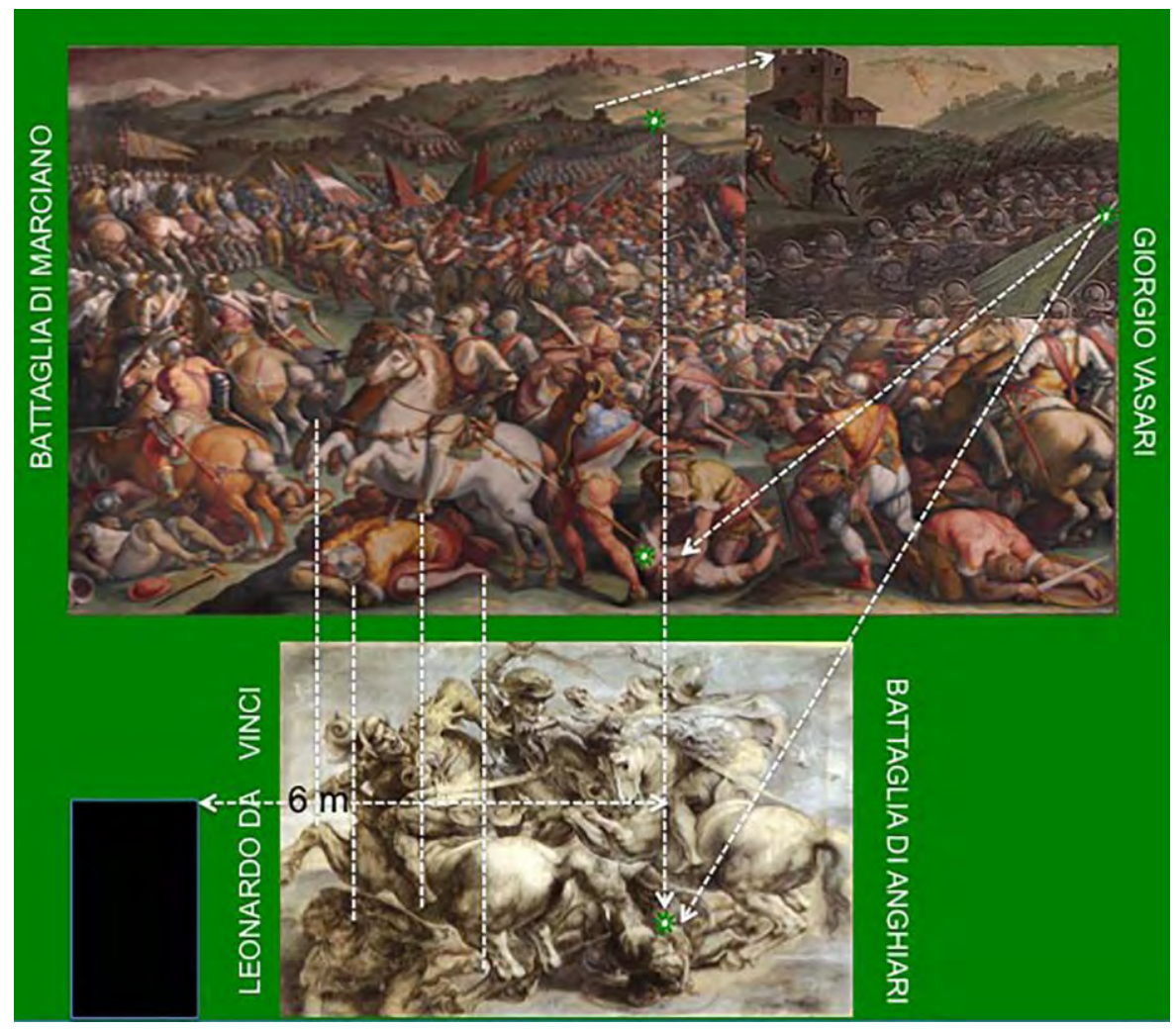

Figure 14. Close up of the relationship between Battaglia di Marciano and Battaglia di Anghiari

Strangely, the open mouth of the soldier being killed on the ground of Battaglia di Marciano lies on the same line that comprises the open mouth of the soldier being killed on the ground of Battaglia di Anghiari and the tip of the banner that carries the words "CERCA TROVA." Notwithstanding that and four additional coincidences, I am uncertain about a positive result, since most paradises dreamt by explorers of the unknown become hells sooner than expected. Because his humbleness had overcome his arrogance in jail, only the Biblical Joseph could dream during the day the truths concealed in the nocturnal dreams of others.

\section{Concluding Remarks}

Joseph was in jail when the ruler of Egypt had two dreams that no sage could explain: Seven lean cows ate seven fat cows; and seven thin heads of grain swallowed seven full heads. Pharaoh's cupbearer, who had accompanied Joseph in prison, told him that someone could help him interpret his dreams (seeing) and choose the best course of action (will).

Most members of the three Syriac religions (Christians, Muslims, and Jews) know that Pharaoh summoned the prisoner. Joseph explained to Pharaoh that his dreams meant that seven years of abundance would be followed by seven years of famine. At that point in time, Pharaoh' seeing and will helped him decide to forfeit the unwanted future, and he named Joseph Vice-Pharaoh. ${ }^{7}$

The account of Pharaoh and Joseph shows that nocturnal dreaming will lead to diurnal dreaming if a powerful leader listens to the thoughts of his humblest constituents, instead of listening to the thoughtless thoughts of his advisers or to his own hallucinating thoughts.

The prophet Zechariah wrote about a world without Pharaoh and Joseph, ${ }^{8}$

\footnotetext{
${ }^{7}$ The Famine Stela asserts that 1000 years before Joseph, seven years of famine corresponded to a decrease of flooding by the Nile. At the time, Pharaoh Djoser called Vice-Pharaoh Imhotep-Asclepius, who told him to pray to the triad headed by the god Khnum, in the city of Elephantine. Khnum appeared to Djoser in a dream and promised him that he would make the Nile grow again. Imhotep built silos that could store wheat for 7 years, the first school of medicine, and the first pyramid.

${ }^{8}$ My translation from Katznelson(1991).
} 
Wake up, oh my sword, against my shepherd and against the man nearer to me, says the Eternal. (13:07)

Hurt the shepherd and the sheep will scatter, and I will turn my hand on the young ...

Two parts of all Earth will die, but the third one will last (13:08).

Although Zechariah seems to prophesize that the young will not inherit the Earth, his contemplation of a chaotic worst-case scenario also offers a best-case scenario! On the wake of bodhisattvas, any person may try to become a "tathā-gatha." The dance of the staff Hovalim with the staff No'am, of the crystal Thummim with the crystal Urim, or of the first with the second attention, could save Earth's biota and us. Still, we need more than bands of tathāgathas.

As previously stated, the theory of solar forcing developed by Milutin Milankovitch in the 1920s (Hays, Imbrie, \& Shackleton, 1976; Milankovitch, 1998) agrees with the facts presented in Figure 11. The variation of atmospheric temperature in Figure 11 shows why approximately 7000 years ago the Sahara desert was a lush paradise in which elephants and lions roamed the future largest concentration of fossil water in the world; namely, the Nubian sandstone aquifer.

A view of precession, obliquity, and eccentricity for the next 100000 years (Berge \& Loutre, 1991; Graham, 2000; and Hays et al., 1976) suggests that within the next seven thousand years, the Northern Hemisphere will move toward glaciation. With this information in mind, it would seem that only our injudiciousness will make true Zechariah's infernal prophecy. Allowing the average temperature of the lower atmosphere to exceed an increase of $2^{\circ}$ Celsius will lead to a veritable inferno. Dante wrote at the inlet of his Inferno, "Lasciate ogni speranza voi ch'intrate," ("Abandon any hope you who enter"). ${ }^{10}$ The insight of Tim Barckholtz at ExxonMobil (2016) about generating power by sequestering $\mathrm{CO}_{2}$ trough a fuel cell, however, invites us to hope that bands of young lions will roam again the Sahara.

In my opinion, if humanistic bands of tathāgathas and of CEOs aimed at reducing by $2^{\circ} \mathrm{C}$ the average temperature of the atmosphere at sea level and at redirecting the terror-loaded malice of the quantum devil that "lies" in the depth of implicit self, humans will avoid the loss of the staffs No'am and Hovalim and reach instead the central place that welcomes the crystals Urim and Thummim.

The viewpoints presented in this paper are my own as a result of interpreting research under the shadow of the logos heuristic; nonetheless, the data, calculations, and hypotheses presented in this paper may be wrong. Yet I hope that an insightful debate and additional research will convince the returning Quetzalcoatl to help us seek the progress of Earth's biota from now to the next glaciation.

\section{Acknowledgements}

I am grateful to Edward Strother and Clayton Cassella for their suggestions.

\section{Brief Biography of Antonio Cassella:}

Web page by placing the words "Antonio Cassella" in the space of the author at Amazon Kindle.

Ed.D. (Teaching and Research, UNESR: Universidad Nacional Experimental Simón Rodríguez, Caracas);

M.Sc. (Psychology, Harvard University, Cambridge [MA]);

B.Sc. (Petroleum Engineering, LUZ: La Universidad del Zulia, Maracaibo).

Antonio Cassella was born in Ethiopia in 1940. He enjoyed his high-school education in Italy and in Venezuela. He obtained a B.Sc. in Petroleum Engineering in Venezuela in 1965. In the next 17 years Antonio developed new oil fields in the tidal bay of Maracaibo with Creole Petroleum Corporation (a subsidiary of Esso/ExxonMobil), Lagoven SA, and PDVSA (Petróleos de Venezuela). A one-year pause led him to working in 1976 for EPRCO (Exxon Production Research) in Houston.

Between 1983 and 1993 Cassella worked in Strategic Planning of PDVSA in Caracas. As a visiting scientist at MIT-CEEPR (Center for Energy and Environmental Policy Research, Cambridge [MA]), between 1994 and 1997 his

\footnotetext{
${ }^{9}$ The Buddha called himself "Tathāgatha." The words mean, "thus gone and thus come"- a reference to the quantum coherence of his going and to the decoherence of his coming back to a renewed shared world. The words of the Buddha, "seek your own salvation," suggest that every person may reach the third attention in seeking to become a tathāgatha. As with a bodhisattva, a tathāgatha-to-be will embrace neither the rigid or chaotic thinking attached to the first attention nor the ambition that misuses the second attention. He or she will take the hard path of welcoming kind thoughts (vision) and kind deeds (will) in bringing his or her third attention to meditate with others.

${ }^{10}$ My translation.
} 
diurnal research led to establishing two global scenarios of population, energy, and economic growth until 2060. In June 1997 his nocturnal research on the psychological roots of autism and creative intelligence brought him the Award for Outstanding Thesis in the Area of Natural and Human Sciences at Harvard University.

In 2001 Antonio Cassella received in Caracas a Doctorate in Research and Teaching in Sciences of Education from UNESR. His writings in Italian, Spanish, and English (at Amazon Kindle) show that combining the rigid conservation sought by our autistic side with the flexible renovation sought by our artistic side may help modern society to defuse fanaticism and global warming while regenerating the Commons of the Earth.

\section{References}

Andrew, G. (1999). The epic of Gilgamesh. London: Penguin Books.

Anonimo, G. (16 ${ }^{\text {th }}$ century; 1893; 26 maggio 2014, fol. 121). Il Codice dell'Anonimo Gaddiano nella Biblioteca nazionale di Firenze. http://vinciana.blogspot.com/2014/05/1893-c-de-fabriczy-il-codice.html

Anonymous. (2003). Popol Vuh: Sacred book of the Maya people. (Translation and comments by Allen J. Christenson). Mesoweb Publications.

B. P. (June, 2016). Statistical review of world energy. London: British Petroleum.

Baktivedanta, A. C., \& Swami, P. (1972, 1987). Bhaghavad Gita as it is. Los Angeles (CA): The Bhaktivedanta Book Trust.

Baron-Cohen, S., Leslie, A. M., \& Frith, U. (1985). Does the autistic child have a 'theory of mind?' Cognition, 21, 37-46. https://doi.org/10.1016/0010-0277(85)90022-8

Berge, A., \& Loutre, M. F. (1991). Insolation values for the climate of the last 10 million years. Quaternary Science Reviews, 10(4), 297-317. https://doi.org/10.1016/0277-3791(91)90033-Q

Caramazza, A. (1994). Parallels and divergences in the acquisition and dissolution of language. Philosophical Transactions of the Royal Society of London, Series B. 346, 121-127. https://doi.org/10.1016/0277-3791(91)90033-Q

Cassella, A. (1997). Self-other differentiation and self-other integration from the perspectives of language development and autism. (Unpublished master's thesis). Harvard University, Cambridge, USA.

Cassella, A. (2000). Fundamentos cognitivos y semióticos de la creatividad: Aportes del autismo. (Tesis doctoral con mención publicación). Universidad Nacional Experimental Simón Rodríguez (UNESR), Caracas, Venezuela.

Cassella, A. (2002a). El desarrollo de la inteligencia social: Aportes del autismo. Maracaibo, Venezuela: Ediluz.

Cassella, A. (2002b). The Flameless Fire: From autism to creative intelligence. Quincy (MA): Logosresearch. (Re-edited through Amazon Kindle in a digital format by Research Autism in 2017; https://www.amazon.com/s?ie=UTF8\&page=1\&rh=n\%3A133140011\%2Cp_27\%3AAntonio\%20Cassella).

Cassella, A. (2008). Readjusting what we know with what we imagine. In R. Allen (Ed.) Human ecology economics: A frameworkfor global sustainability (pp. 230-257). London: Routledge.

Cassella, A. (2011, June). Autism and the interplay of deterministic and quantum information processing in the act of creation. Neuroquantology, 9(02), 271-287.

Cassella, A. (2013). Neurobiological correlates of classical and quantum neural computing from the perspective of autism. In V. B. Patel, V. B. Preedy, \& C. R. Martin (Eds.), The comprehensive guide to autism (pp. 865-890). London: Springer. https://doi.org/10.14704/nq.2013.11.2.623

Cassella, A. (2016a). Thus returned Quetzalcoatl: An interview with Antonio Cassella concerning the Dance of locality and nonlocality. Melbourne (FL): Research Autism https://www.amazon.com/s?ie $=$ UTF8\&page $=1 \& \mathrm{rh}=\mathrm{n} \% 3 \mathrm{~A} 133140011 \% 2 \mathrm{Cp} \_27 \% 3$ AAntonio\%2 0Cassella.

Cassella, A. (2016b). The psychological roots of creativity in messages left by Leonardo da Vinci, Giorgio Vasari, and a Neanderthal troglodyte. Journal of Arts and Humanities, 5(8), 12-28.

Cassella A. (2016c). An unlawful look at an extraordinary theory-of-everything: Answers to fifteen questions concerning the dance of locality with nonlocality. Melbourne (Florida): Research Autism. https://www.amazon.com/s?ie=UTF8\&page=1\&rh=n\%3A133140011\%2Cp_27\%3AAntonio\%20Cassella

Castaneda, C. (1972). Journey to Ixtlán: The lessons of Don Juan. New York, NY: Simon and Schuster.

Castaneda, C. (1991). The Eagle's gift. New York, NY: Simon and Schuster. 
Castaneda, C. (1968). The teachings of Don Juan: A Yaqui way of knowledge. New York, Simon and Schuster, 1968.

Courchesne, E., To wnsend, J. P., Akshomoof, N. A., Yeung-Courchesne, R., Press, J. A., Murakami, J. W., ...Schreibman, L. (1994). A new finding: Impairment in shifting attention in autistic and cerebellar patients. In S. Broman \& J. Grafman (Eds.), Atypical cognitive deficits in developmental disorders: Implications for brain function (pp. 101-137). Hillsdale, N.J: Erlbaum.

ExxonMobil. (2016, May 5). What if we could stop carbon dioxide emissions from power plants" Science \& Technology (Energy Factor). https://energyfactor.exxonmobil.com/category/science-technology/

Faires, V. (1962). Thermodynamics. New York: Macmillan, 1962.

Gornitz, V. (2012). The great ice meltdown and rising seas: Lesson for tomorrow. NASA Science Briefs. https://www.giss.nasa.gov/research/briefs/gornitz_10/

Graham, S. (2000). Milutin Milankovitch (1879-1958). NASA Earth Observatory (https://earthobservatory.nasa.gov/Features/Milankovitch/milankovitch.php).

Hays, H. D., Imbrie, J., \& Shackleton, N. J. (1976). Variations in the Earth's orbit: Pacemaker of the Ice Ages. Science, 194(4270), 1121-1132. https://doi.org/10.1126/science.194.4270.1121

Icke, V. (1995). The force of symmetry. Cambridge: Cambridge University Press. https://doi.org/10.1017/CBO9780511622694

IPCC-WG1. (2007). Intergovernmental Panel on Climate Change. Fourth Assessment Report. Summary for Policymakers: A Report of Working Group I. IPCC-WMO.

IPCC-WG1. (2014). Intergovernmental Panel on Climate Change. Fifth Assessment Report. Summary for Policymakers: A Report of Working Group I. IPCC-WMO.

Johnson, M. H. (1994). Visual attention and the control of eye movement in early infancy. In C. Umiltà \& M. Moscovitch (Eds.) Attention and performance XV: Conscious and nonconscious information processing (pp. 291-310). Cambridge (MA): The MIT Press.

Katznelson, M. (1991). La Biblia: Hebreo-Español. Tel Aviv: Sinai.

Lao Tze. (1891). Tao Te Ching. Oxford: Oxford University Press.

Landry, R., \& Bryson, S. (June, 2004). Impaired disengagement of attention in young children with autism. Journal of Child Psychology and Psychiatry, 45(6), 1115-1122. https://doi.org/10.1111/j.1469-7610.2004.00304.x

Milankovitch, M. (1998). Canon of insolation and the ice-age problem. Belgrade: Textbook Publishing Company.

Miller, K. G. (Accessed May 11, 2017). Sea level change. Last 250 million years. Introduction. (p. 879). http://static.springer.com/sgw/documents/650498/application/pdf/978-1-4020-4551-6_Sea+Level+Change\%2C+L ast $+250+$ Million+Years_Miller_web.pdf

NOOA. (2006). Late Quaternary sea level history. (The image was loaded on Wikimedia commons in 2006). https://commons.wikimedia.org/wiki/File:Sea_level_temp_140ky.gif

Piaget, J. (1983). La psicología de la inteligencia. Barcelona: Grijalbo.

Povinelli, D. J., Landau, K. R., \& Perilloux, H. K. (1996). Self-recognition in young children using delayed versus live feedback: Evidence of a developmental asynchrony. Child Development, 67, 1540-1554. https://doi.org/10.2307/1131717

Ruppert, T. (2014). Sea-level rise in Florida-the facts and science. University of Florida, Gainesville. https://www.flseagrant.org/wp-content/uploads/SLR-Fact-Sheet_dual-column-letterhead_4.18.14_FINAL.pdf

Ward, P. D. (October, 2006). "Impact from the Deep." Scientific American, 295, 64-71. https://doi.org/10.1038/scientificamerican1006-64

Zaitchik, D. (1990). When representations conflict with reality: The preschooler's problem with false beliefs and 'false' photographs. Cognition, 35, 41-68. https://doi.org/10.1016/0010-0277(90)90036-J

\section{Copyrights}

Copyright for this article is retained by the author(s), with first publication rights granted to the journal.

This is an open-access article distributed under the terms and conditions of the Creative Commons Attribution license which permits unrestricted use, distribution, and reproduction in any medium, provided the original work is properly cited. 